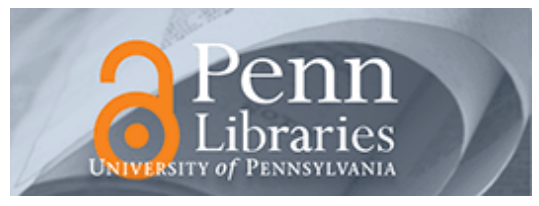

University of Pennsylvania

ScholarlyCommons

Management Papers

Wharton Faculty Research

6-2012

\title{
A Reexamination of Tunneling and Business Groups: New Data and New Methods
}

Jordan Siegel

Prithwiraj Choudhury

University of Pennsylvania

Follow this and additional works at: https://repository.upenn.edu/mgmt_papers

Part of the Business Administration, Management, and Operations Commons

Recommended Citation

Siegel, J., \& Choudhury, P. (2012). A Reexamination of Tunneling and Business Groups: New Data and New Methods. The Review of Financial Studies, 25 (6), 1763-1798. http://dx.doi.org/10.1093/rfs/hhs008

This paper is posted at ScholarlyCommons. https://repository.upenn.edu/mgmt_papers/88

For more information, please contact repository@pobox.upenn.edu. 


\title{
A Reexamination of Tunneling and Business Groups: New Data and New Methods
}

\author{
Abstract \\ One of the most rigorous methodologies in the corporate governance literature uses firms' reactions to \\ industry shocks to characterize the quality of governance. This methodology can produce the wrong \\ answer unless one considers the ways firms compete. Because macro-level shocks reverberate \\ differently at the firm level depending on whether a firm has a cost structure that requires significant \\ adjustment, the quality of governance can only be elucidated accurately analyzing a firm's business \\ strategy and their corporate governance. These differences can help one determine whether the fruits of \\ a positive macro-level shock have been expropriated by insiders. Using the example of Indian firms, we \\ show that an influential finding is reversed when these differences are considered. We further argue that \\ the conventional wisdom about tunneling and business groups will need to be reformulated in light of the \\ data, methodology, and findings presented here.

\section{Disciplines} \\ Business Administration, Management, and Operations
}




\title{
A Reexamination of Tunneling and Business Groups:
}

\author{
New Data and New Methods
}

\author{
Jordan Siegel* and Prithwiraj Choudhury \\ Harvard Business School and The Wharton School \\ First partial draft: July 17, 2007 \\ This Draft: Version 1.88, August 14, 2011
}

The corporate governance literature of the past decade has focused on identifying drivers of superior or deficient corporate governance. One of the most rigorous methodologies uses firms' reactions to industry shocks to characterize the quality of governance. We propose that this methodology can produce the wrong answer unless one takes into account the different ways in which firms compete (that is, their business strategy). Because macro-level shocks reverberate differently at the firm level depending on whether a firm has a cost structure that requires significant cost adjustment, the quality of governance can only be elucidated accurately by means of simultaneous analysis of firms' business strategy and their corporate governance. Only by acknowledging these differences in cost structure can one determine whether the fruits of a positive macro-level shock have been expropriated by a firm's insiders. Using the example of Indian firms, we show that an influential finding is reversed when we take these differences into account. We further argue that the conventional wisdom about tunneling and business groups will need to be reformulated in light of the data, methodology, and findings presented here.

* The corresponding author can be contacted at jsiegel@hbs.edu, Morgan Hall 231, Soldiers Field, Harvard Business School, Boston, MA 02163. The authors are grateful for comments and criticisms from Laura Alfaro, Sharon Belenzon, Utpal Bhattacharya, Kathryn Dewenter, Artyom Durnev, Ann Goodsell, Vit Henisz, Adrianna Lohnes, Rosalyn Reiser, Richard Siegel, Eric Van den Steen, Toni Whited, Yishay Yafeh, Sai Yayavaram, Mark Zbaracki, and seminar and conference audiences at Duke University, Washington University in St. Louis, Northeastern University, George Washington University, the National University of Singapore, and the University of Western Ontario. The usual caveat applies. 


\section{Introduction}

Is our understanding of corporate governance misleadingly incomplete if we do not take into account the different ways that firms in a given industry compete? Firms make different core choices about the degree to which they recombine inputs purchased elsewhere to create something more valuable. Some firms merely touch up inputs and are little more than resellers; at the other end of the spectrum are firms that recombine inputs in more complex, knowledge-based ways to add functionality and increase consumers' willingness to pay. The decision to be a reseller or a recombiner of inputs is a core choice in applied microeconomics; in fact, it is a primary focus of an entire field of academic inquiry, inspired by microeconomics and industrial organization economics, known as the Strategy field. (Michael Porter is widely considered the father of the modern Strategy field; see Porter 1980, 1985, 1996.)

The choice of business strategy over time significantly determines corporate governance in logical ways, and only by directly analyzing business strategy can the quality of corporate governance be effectively assessed. The detailed statistical model presented here powerfully illustrates the critical importance of analyzing business strategy in the service of identifying superior or deficient corporate governance. It turns out that a neighboring firm's windfall may not predict the focal firm's windfall, even within the same industry, if the neighboring firm is pursuing a different business strategy.

Suppose that the neighboring firm's business strategy is essentially to resell inputs, while the focal firm uses firm-specific knowledge to recombine inputs into something more sophisticated. In the event of a positive shock to demand, the neighboring firm's operating costs do not change as the focal firm's do. Only the focal firm will respond to a sudden positive shock with an increase in recombination activities, thus incurring associated costs. We can only assess the quality of the focal firm's corporate governance accurately, therefore, by taking into account its choice of business strategy. When we do so, we find that many of the firms implicated in the literature's well-known finding that Indian business groups are typically expropriators, are actually honest actors engaged in value creation; further, we find no evidence that they are expropriators. (Of course, there is a nontrivial minority of expropriators in the Indian economy, and our methodology can also be useful for identifying the truly bad actors.) 
The most generalizable and rigorous methodology in the modern corporate governance literature to date was proposed by Bertrand, Mehta, and Mullainathan (2002) in the Quarterly Journal of Economics. By examining sudden changes in the profitability of a focal firm's industry peers, they argued, one can measure whether the focal firm was reacting to sudden changes in industry profitability and then use that measure to assess the quality of the firm's corporate governance. This insight has power and simplicity because it uses an external reference point to evaluate how a firm is governed. The methodology also allows researchers to use firm-level fixed effects and thus to control for time-invariant firm heterogeneity.

Bertrand et al.'s 2002 study has been immensely influential. Their results have been hailed for cementing the conventional wisdom about tunneling and business groups in prominent review articles by Morck, Wolfenzon, and Yeung (Journal of Economic Literature 2005) and Bebchuck and Weisbach (Review of Financial Studies 2010), and cited over 90 times in 2002-2010 according to the Social Science Citation Index.

Despite its influence, however, Bertrand et al.’s methodology overlooked the crucial role of business strategy in corporate governance. It was also plagued by four further shortcomings that also contributed to inaccurate results. First, Bertrand et al. did not mention that the database they used, the Prowess database compiled by the Center for Monitoring Indian Economy (CMIE), had an explicit survivorship bias during the period of their study: in that early phase of its development, the CMIE systematically omitted all historical observations of companies that eventually failed, ceased to exist independently, or failed to provide disclosure for three consecutive years. In other words, Bertrand et al.'s study of performance differences did not acknowledge that the least successful firms had been eliminated from their sample. Our sample consists of over 47,000 observations for the years 1989-1999; for the same period Bertrand et al. had under 19,000 observations because their sample omitted a very large number of firms. Another reason for the difference in sample size is that over time CMIE expanded its inclusion criteria to encompass an incrementally larger percentage of the economy. (Our findings are consistent, however, even when using the sample-inclusion criteria from the time of Bertrand et al.'s 
study along with the graveyard set from that era.) After Bertrand et al.'s study, the survivorship-bias problem was eliminated when the CMIE, in a letter to its subscribers, publicly announced reincorporation of the historical graveyard set into its data. More recent observations no longer have a survivorship bias. Second, Bertrand et al. did not deal with heteroskedasticity concerns. Though their dependent variable was raw operating profit unscaled by size or assets, no attempt was made to deal with the serious problem of heteroskedasticity. When the residuals are plotted against the fitted values, and when the Breusch-Pagan test is conducted, we see clear evidence of heteroskedasticity in the Indian corporateperformance data.

Third, Bertrand et al. did not deal with serial autocorrelation issues. Despite a 1989-1999 panel data set characterized by as many as 11 observations of the same firm, their implemented methodology did not take into account the likelihood of serial autocorrelation in performance at the firm level. There is a certain irony here, in that two of the study's authors circulated an influential paper the same year faulting other academics for failing to take serial autocorrelation seriously (Bertrand, Duflo, and Mullainathan, NBER 2002). Serial autocorrelation, heteroskedasticity, and survivorship bias jointly led to sharply inflated coefficient estimates and underestimated standard errors in Bertrand, Mehta, and Mullainathan (2002).

Fourth, Bertrand et al.'s models linked precise percentages of insider cash-flow ownership within a business group to expropriation, but did not disclose the serious shortcomings of its corporateownership data. Specifically, at no point did they disclose that in that era a very high percentage of eligible Indian firms—even publicly listed firms—disclosed precise percentages of insider cash-flow ownership only when they felt like it, if at all. The holes in the data are severe, thus introducing significant sample-composition bias. In part because of those holes, the data provider no longer distributes those corporate-ownership variables from the 1990s. The data provider referred us to a respected Indian academic who had previously downloaded all the corporate-ownership data from the 1990s, and as a robustness check we ran the regressions and found results materially different from those reported by Bertrand et al. 
The development of rigorous methodology to study corporate governance is not merely an academic issue; it has enormous real-world consequences. It may influence how legislators, regulators, and law-enforcement officials in emerging economies prioritize their institutional efforts to ensure highquality corporate governance. Tunneling is an exceptionally serious problem in emerging economies due to weak legal institutions (Johnson et al. 2000; Siegel 2005). Deeper empirical and theoretical insights into the question of whether business groups serve primarily as theft devices (the dominant view in the economic and finance literatures) or as an agglomeration technology that enables scale-and-scope efficiencies (the dominant view in the business strategy literature) are critically needed.

A business group is in essence a leverage device: it enables a single entrepreneur to control vast knowledge-creating resources and assets with a fraction of the capital that would be needed by a standalone entity. Firms within the group band together to fund investments and start-ups and to share production, R\&D, and marketing knowledge. Our view of business groups posits that such groups make possible complex recombinations of inputs that would rarely be feasible for a stand-alone firm. Via joint leveraging of knowledge and finance, these groups can take on far more complex production challenges. The question is whether business groups are actually being used to accomplish such a value-creating, sophisticated recombination of inputs. The alternative scenario is that their controlling owner-managers abuse their control over group affiliates to pilfer the invested resources of minority investors. This is a multi-trillion-dollar question of emerging-economy development, since business groups as an organizational form are responsible for the vast majority of sales, assets, and value added in India (see Table 1) and other emerging economies.

Two prior publications are particularly pertinent to our work. As noted, we differ from Bertrand et al. (2002) in (a) our emphasis on differences in firms' business strategies, (b) a methodology that simultaneously analyzes strategic-activity choices and corporate governance, and (c) a theory of business groups newly focused on unique business strategies. In the corporate governance literature, our study most closely resembles that of Dharmapala and Khanna (2008), who tested for the effect on tunneling of post-1999 changes in Indian governance institutions and did not find a significant group effect. Those 
authors attributed the lack of statistical significance in their regression result to a time-period effect and did not question the earlier result. Nor did they posit or investigate any explanation for the non-result in their study, except to suggest that corporate governance might have changed radically after 1999 and that groups might have become more constrained.

In sum, our paper presents several new empirical findings. First, we show that throughout the two decades after Indian liberalization (1989-2008) the business strategies of business group-affiliated firms differed systematically from those of stand-alones in the same industry. Group-affiliated firms were on average more intensely engaged in recombination of economic inputs; private stand-alones tended to resell existing finished goods. Second, we show that, upon closer examination, most Indian business groups should not be viewed as theft devices; in fact, they react quite positively to industry shocks. Third, we show that Indian groups pay significantly more taxes than stand-alones per same unit of sales. ${ }^{1}$ (It is important to emphasize that Indian business groups do not pay a different tax rate.) Fourth, we find that Indian business groups become larger and more diversified as market institutions develop. This finding contradicts the predictions and implications of all prior schools of thought about business groups, including that of Bertrand et al. (2002). Fifth, we find that Indian business groups continue to tower over stand-alones in their marketing- and technology-related investment intensity as market institutions develop. This stands in contrast to the implication of all prior views about business groups, including that of Bertrand et. al. (2002), that the business groups' competitive advantage is in part based on the existence of weak governance and other institutions at the country level, and that the competitive advantage of groups should dissipate with institutional development.

The rest of the paper is organized as follows: Section II describes the data and presents a series of summary statistics; Section III presents the model and results. Section IV discusses the results, and Section V presents our conclusion.

\footnotetext{
${ }^{1}$ We cannot discount the possibility that stand-alones more often underpay their taxes; we cannot test for that possibility with currently available data. Also, it is important to emphasize that this study is not about evaluating whether Indian business groups are "good guys," since such a value judgment from our vantage point would require knowing how each firm gave to politicians and what social externalities are produced by each firm's business activities. This study is squarely focused on the treatment of outside investors and relative efficiency considerations.
} 


\section{Data and Summary Statistics}

IIA. Data

Our data come from the Prowess database, a subscription-based data source maintained by the Center for Monitoring Indian Economy (CMIE), an independent economic think tank based in Mumbai. CMIE was founded in 1976 by the economist Narottam Shah; by 2009 it employed 330 researchers and others in 17 offices across India. CMIE is the most trusted source of data on Indian companies' financial statements and business group affiliations, and its data has been used in numerous academic studies in corporate finance and strategic management, including that of Bertrand, Mehta, and Mullainathan. CMIE's historical product manuals provide an exhaustive description of every variable, and CMIE is meticulous in its efforts to correct for differences in how Indian companies combine or segment financial items.

We utilize longitudinal data from the Prowess data set on public and privately held firms from fiscal years 1988-1989 through 2007-2008. For simplicity, we will refer to this period as 1989-2008, the years in which these companies issued their annual reports. By the time of our data download in October 2009, the Prowess data set for this period covered over 22,000 Indian firms; it included all public firms listed on India's main stock exchanges and the vast universe of medium-sized and large privately held firms, and it tracked firm-level death and entry. The Prowess data set encompasses over 1,500 financial variables and ratios on each firm's balance sheets, profit-and-loss statements, and cash-flow statements, starting in 1989. Like Bertrand, Mehta, and Mullainathan, we exclude state-owned and foreign-owned firms (until we arrive at a series of robustness checks) because our primary goal is to compare firms owned by Indian business groups to stand-alones. And again like Bertrand, Mehta, and Mullainathan, we rely on CMIE's designation of a given firm as independent or as a member of a business group. By checking all M\&A transactions reported in the Thomson Reuters SDC database during the 1989-2008 time period, we found a handful of uncoded changes in group affiliation; those few cases had no significant effect on the results. 
We utilize the following variables, each measured in Indian crore ( 1 crore $=10$ million rupees) and converted to constant 1995 currency following Bertrand, Mehta, and Mullainathan (2002). For firm size, we use the firm's total assets over time (Total assets), by taking the log of total assets (Ln assets). In other models, we utilize the firm's total annual revenues (Total sales). Further following Bertrand, Mehta, and Mullainathan, we frequently focus on firms' annual profits before depreciation/amortisation, interest, and taxes (PBDITA). ${ }^{2}$ Because this measure of profit includes one-time transactions and extraordinary income, we also run robustness checks using annual profits before depreciation/amortisation, interest and taxes but net of extraordinary income and one-time transactions (PBDITA net of NOI and NNRT). Following the same example, we also control for the firm's year of incorporation (Year of incorporation).

Further following Bertrand, Mehta, and Mullainathan, we measure industry shocks and then calculate a predicted profit for each firm based on the profit shock experienced by the other firms in the same industry. The first step is to add up the profits of a given industry in each year and the total assets of the industry in each year (subtracting out those of the focal firm from each firm-year observation). The next step was to take the industry’s ROA for a given year (subtracting out that of the focal firm) and multiply it by the focal firm's asset size in that year to predict what the firm would earn given the industry shock (Own shock). This variable is then multiplied by a group-affiliation dummy to separately test the effect of being a group affiliate (as opposed to being a stand-alone firm). The Own shock variable is also interacted with firm size and year of incorporation for purposes of replicating Bertrand, Mehta, and Mullainathan's results. For a series of robustness checks, we further include key control variables in the model by controlling for leverage, leverage interacted with Own shock, export orientation, export orientation interacted with Own shock, trading-based sales, trading-based sales interacted with Own shock, excise tax paid, and excise tax paid interacted with Own shock.

\footnotetext{
${ }^{2}$ In historical versions of Prowess referenced in Bertrand et al. (2002), this variable was abbreviated as PBDIT. The abbreviation was later changed to PBDITA by CMIE to signify that it represents firms' profits before depreciation, interest, taxes, and amortization. That the profit variable used in Bertrand et al. (2002) and here are one and the same was confirmed in a communication to the author from CMIE on November 12, 2009.
} 
Again following Bertrand, Mehta, and Mullainathan (2002), we sought to test whether tunneling increases when insiders with a low percentage of cash-right ownership exercise control, and whether this phenomenon is compounded when insiders control a business group. Since 2002, Prowess has stopped providing historical shareholder-ownership data for the period 1989-2001 (and for most of the 20012006 time period for most firms), in part because few firms voluntarily reported shareholder ownership. (A large percentage of publicly listed firms, which were required to report, also failed to do so.) We were given a separate download of 1989-1999 shareholder-ownership data by a referral from the CMIE, and we ran a robustness check on that data. Following Bertrand, Mehta, and Mullainathan (2002), we examined both the percentage of ownership held by directors and that held by outside others.

In order to understand how firms in the same industry pursue significantly different types of activities, we examine the extent to which firms engage in value-creating recombinations of inputs, as proxied by excise taxes paid divided by total sales. It is important to note that excise taxes during the period in question were entirely a matter of uniform national rules, with the sole exceptions of taxes on alcohol and narcotic substances, which were set at the state level. ${ }^{3}$ A comparable proxy for these withinindustry differences is sales from trading finished goods divided by total sales.

One of our principal contributions to the corporate governance literature is to acknowledge differences in firms' strategic activities. Specifically, we examine how industry shocks affect firms differently depending on differences in their strategic activities. Thus we examine the effect of industry shocks on firm-level changes in advertising, marketing, power, fuel-and-water expense, repairs and maintenance of plant and machinery, miscellaneous expenditure/residual SG\&A, other amortization, provisions for bad/doubtful advances, total provisions, kWh usage of electricity, and directors' remuneration, while controlling for such other key variables as size, year, and firm fixed effects. Though most of our analysis excludes government-owned and foreign-owned firms (as did Bertrand, Mehta, and Mullainathan), we also run a series of robustness checks in which they are included.

\footnotetext{
${ }^{3}$ This information was attained from http://www.cbec.gov.in/faq.htm on September 3, 2009.
} 
In one of our final analyses, we examine the predictions of prior schools of thought that business groups would be forced to retrench as market institutions develop. Specifically, we examine the number of each group's affiliates and the number of three-digit industries represented by its affiliates; these data too came from CMIE Prowess. We also look at how the relatedness of Indian business groups' diversification changed over the 1989-2008 time period, using information on industries' input-output relatedness from the 2006-2007 Indian Industry Input-Output Tables. ${ }^{4}$

\section{IIB. Summary Statistics}

The summary statistics in Table 1 show that group-affiliated firms in India are typically larger, more profitable, and slightly older than stand-alones. Foreign-owned and government-owned firms are typically larger than both group-affiliated firms and stand-alones; the former also include more outliers in terms of performance. When we exclude performance outliers, we find foreign-owned firms to be the most profitable on average, but by a slim margin over group-affiliated firms. Foreign-owned and government-owned firms also tend to be older than stand-alones, but foreign-owned firms are on average similar in age to group affiliates.

\section{Model and Results}

Table 2 replicates Bertrand, Mehta and Mullainathan’s results. The model regresses a firm’s realized profit on its predicted profit (based on that of the rest of the firm's industry), and on that predicted profit interacted with group affiliation, as well as on firm size, firm size interacted with predicted profit, and the year of incorporation interacted with predicted profit. All time-invariant firm characteristics are controlled for through firm fixed effects, and the effect of time-period effects is controlled for through year dummies. Thus the basic model, which we will build on later, is:

(1) $\operatorname{perf}_{\mathrm{kt}}=\mathrm{a}+\mathrm{b}\left(\operatorname{pred}_{\mathrm{kt}}\right)+\mathrm{c}\left(\operatorname{group}_{\mathrm{k}} * \operatorname{pred}_{\mathrm{kt}}\right)+\mathrm{d}\left(\operatorname{controls}_{\mathrm{kt}}\right)+$ Firm $_{\mathrm{k}}+$ Time $_{\mathrm{t}}$,

\footnotetext{
${ }^{4}$ The input-output tables, available only for a few years in the past two decades, were downloaded from http://www.mospi.gov.in/cso_rept_pubn.htm in July 2010. The Indian Ministry of Statistics and Programme Implementation made the data available to researchers.
} 
where perf $\mathrm{kt}_{\mathrm{kt}}$ represents firm k’s PBDITA (or, alternatively, its PBDITA net of prior-period and extraordinary income) at time $t$, pred $_{k t}$ is the firm's predicted PBDITA (or, alternatively, its predicted PBDITA net of prior-period and extraordinary income) at time $t$, and $\operatorname{group}_{\mathrm{k}} * \operatorname{pred}_{\mathrm{kt}}$ is the interaction term between pred $\mathrm{kt}_{\mathrm{kt}}$ and the dummy variable for whether a firm is a member of a business group, group $\mathrm{p}_{\mathrm{k}}$ We also include control variables (which increase in number as we proceed toward our full specification), firm fixed effects, and year dummies.

We find in Table 2 that, using the main model of Bertrand, Mehta, and Mullainathan, we are able to replicate their result (that groups are expropriation devices) when not using clustering and robust standard errors. The negative and significant coefficient for group affiliation critically relies on the absence of clustering and robust standard errors.

Bertrand, Mehta, and Mullainathan's experimental design was incomplete in that it did not take into account the possibility that firms in a given industry could systematically differ in their strategic activities. The modern Strategy field has its roots in industrial organization economics and continues to this day to be made up significantly of those trained in industrial organization economics. A core feature of the Strategy literature is that firms within an industry must choose how to compete relative to their peers (Caves and Porter, 1977; Porter, 1996). They aim for a form of competition that will add value (either through raising willingness to pay or lowering cost) and that will be difficult for competitors to steal away (Porter, 1980, 1985, 1996).

In India, the firms have chosen two main forms of competition within an industry: a greater emphasis on reselling finished goods and a greater emphasis on complex recombination of inputs. By the criteria of numerous seminal articles and books in the Strategy literature, this fundamental choice by Indian firms in how to compete is a core strategic decision. In fact, if one examines a seminar Strategy article written by Caves and Porter (1977: 246), they even say that a core investment in product differentiation is what can lead to higher fixed cost intensity, which then leads to a less favorable position for one's competitors. Thus, any differences in operating leverage among Indian firms are an outcome of fundamental choices about technologies, manufacturing process, which people to hire, customers, etc. 
Clearly, the resellers are going to compete with each other more on cost of delivering the already-finished good (thus constituting a low cost strategy), whereas the recombination firms are going to compete with each other more on the ability to differentiate their products and raise willingness to pay (thus constituting a differentiation strategy). ${ }^{5}$

As Table 3 powerfully shows, group affiliates and stand-alones differ systematically in what they do as firms in the business activities they pursue. Group affiliates in India are systematically more likely to recombine inputs to generate added value, and then to pay taxes on that added value. Stand-alone firms, by contrast, are more likely to simply trade/re-sell finished goods made by other firms. The systematic differences are stark. Group affiliates pay two-thirds more in value-added excise tax as a percentage of sales on average than do stand-alone firms. Group affiliates derive a significantly lower percentage of their total revenues from trading/re-selling finished goods, but this difference does not account for the entire difference between the two types of firms in excise taxes paid divided by sales. Clearly, even when stand-alones manufacture goods, they don't perform as much value-added recombination as do group affiliates, on average. Interestingly, the two types of firms hardly differ in their export orientations, thus ruling out that factor as the cause of their different responses to domestic industry shocks.

\footnotetext{
${ }^{5}$ In finance, operating leverage is a key form of risk, by which, those with higher operating risk have higher fixed costs intensity and gain greater incremental profit from a sudden positive shock while losing far more incrementally from a sudden negative shock. The difference here is that the firms with greater emphasis on complex recombination of inputs (which effectively means higher fixed cost intensity during stable economic times) actually see smaller incremental profit from a sudden positive shock because their variable costs shoot up. Also, many independent stand-alones simply don't have even have costs like plant repair bills or steep peak-time electricity spikes to pay. Therefore, the independent stand-alones with lower fixed cost intensity during stable times actually see higher highs and lower lows during shocks. So the present situation is a case where different strategies led to different costs structures, where some firms don't even have anything for a given set of cost items. This in turn leads to a differential response to a sudden increase in demand. Thus, the present situation is quite different from the classic story of operating leverage in finance, such as the one for hotels told in Rushmore (1997). True, the reseller-oriented firms may have higher incremental fixed cost intensity during a shock-because they don't have incremental spikes in variable costs during a shock - but this is still distinct from the classic operating leverage story. To understand why a firm could have lower fixed asset intensity during a stable economic period, but higher incremental fixed asset intensity during a sudden industry shock, requires an understanding of deeper strategic choices made by these firms. In other words, what is key to understanding the resellers and the more complex input recombination firms is that they adopted different strategies, which led them to have more of specific cost items and not others, in turn leading to differential reactions to common industry shock. Thus, the difference in fixed cost intensity is real, the fixed asset intensity comparison between the two sets of firms flips during an economic shocks, and one cannot make sense of this symptomatic difference (operating leverage) without going much deeper into the examination of how these firms choose to compete (their business strategy).
} 
We next link our analysis of how firms differ in their strategic business activities to analysis of how firms react differently to shocks. Tables 4 shows the results of an illustrative experiment demonstrating how each strategic activity cost changes when an industry shock occurs. Thus, for the purpose of this very simple illustration, each key operational activity cost is now the alternative dependent variable. We thus estimate:

(2) StrategicActivityCost ${ }_{k t}=a+b\left(\right.$ pred $\left._{k t}\right)+c\left(\right.$ lnassets $\left._{k t}\right)+$ Firm $_{k}+$ Time $_{t}$, where StrategicActivityCost ${ }_{k t}$ represents an increase (or decrease) in the magnitude of firm k's operational activity cost items, including advertising, marketing, repair and maintenance of plant and machinery, power, fuel, and water costs, etc., at time t. In this model, pred ${ }_{k t}$ is the firm's predicted PBDITA (or, alternatively, its predicted PBDITA net of prior-period and extraordinary income) at time t; we also control for the log of firm size, firm fixed effects, and year dummies. We ran these specifications separately for the groups-only subsample and then for the stand-alones-only sample to produce a simple illustration of how these subsamples respond differently to industry shocks. What is presented is the regression coefficient for the shock variable (which represents the impact of the shock on that strategic activity cost item for that subsample). Thus, the larger the positive coefficient, the more a positive shock leads to an increase in that strategic activity cost. Conversely, in the case of negative shocks, the larger the coefficient, the more that strategic activity is reduced; this makes sense, since trading-focused standalones rarely have the same strategic activity costs to cut during a negative shock. The industry shock is still being defined by the total population of groups and stand-alones.

Consistent with the finding that group affiliates more often add value while stand-alones more often trade finished goods, we find in Table 4 that group affiliates react to positive industry shocks by systematically taking on greater expenditures: for advertising and marketing; power, fuel, and water; repair and maintenance of plant and machinery; miscellaneous costs, including higher donations to charity but more importantly a function of higher overall SG\&A expense (miscellaneous expenses are akin to SG\&A in the United States); other amortization; total provisions (especially provisions for bad/doubtful advances to customers, which are treated as an operational expense); and a larger increase in utilization of 
plant and machinery, as evident in a greater increase in kWh of electricity consumed. Stand-alones do not react similarly to industry shocks because they are more likely to be reselling finished goods and doing relatively less recombination of inputs in general. Also, increases in directors' remuneration do not differ meaningfully between group affiliates and stand-alones.

These strategic differences among firms have clear governance implications. Group affiliates are more likely to take on heightened operational expenses in order to benefit from positive industry shocks; stand-alones, by contrast, can simply sell more volume without shouldering comparable operational expenses. For legitimate reasons, therefore, group affiliates should see less incremental profit from an industry shock than do stand-alones. That is, groups find that any incremental revenues they might enjoy from a positive industry shock will in effect be taxed twice, both as intensified operational activity costs and via higher excise taxes at the final net-profit stage. There is thus a legitimate business reason why groups would enjoy more modest windfall profits from a positive industry shock than would stand-alone firms. We can now return to our models with a new understanding that groups might appear to be theft devices when they are simply pursuing positive value-added activities.

Yet, interestingly, the negative group effect on profit disappears when one uses modern econometric methods for clustering at the firm level with robust standard errors. It should be obvious that when the dependent variable is the amount of profit (as opposed to something scaled along the lines of ROA), the standard errors of the uncorrected models in Table 2 are likely to have heteroskedasticity problems. Table 5 shows that the statistical significance of the business group dummy in the main model in fact disappears when we use clustering at the firm level with robust standard errors. Thus policy interventions broadly targeted at all Indian groups and based on an experiment that did not employ modern econometric techniques could be misguided.

We next submit the models to a further series of controls: leverage and export orientation are two strategic choices that could also influence how a firm will be impacted by an industry shock. Table 6 shows that the coefficient for group affiliation is insignificantly different from zero even when we further control for the effects of leverage, leverage interacted with predicted profit, export orientation, and export 
orientation interacted with predicted profit. In Table 7, we further show that the coefficient for group affiliation is insignificantly different from zero even when we add further controls for trading/sales, trading/sales interacted with Own shock, excise/sales, and excise/sales interacted with Own shock.

In Table 8, we perform a robustness check by adding the foreign-owned and government-owned firms. Again, there is no significantly negative effect of group affiliation. Interestingly, government ownership is significantly associated with tunneling in the full models.

In Table 9, we add a battery of further control variables while retaining the foreign-owned and government-owned firms. In this more fully specified model, interestingly, the group affiliation at first appears to be negative and to have some statistical significance. But it is important to keep in mind that any residual negative group effect is an artifact of the group's increased value-added activity costs when responding to a shock. Thus we estimate:

(3) ProfitPlusValuedAddedActivityCost $k=a+b\left(\operatorname{pred}_{k t}\right)+c\left(\operatorname{group}_{k} * \operatorname{pred}_{k t}\right)+d\left(\operatorname{controls}_{k t}\right)+$ Firm $_{\mathrm{k}}+$ Time $_{\mathrm{t}}$

where ProfitPlusValuedAddedActivityCost ${ }_{k t}$ represents firm k’s PBDITA (or, alternatively, its PBDITA net of prior-period and extraordinary income) plus any one or a few core value-added activity costs like power, fuel, and water (energy) expense, at time t; pred $_{\mathrm{kt}}$ is the firm’s predicted PBDITA (or, alternatively, its predicted PBDITA net of prior-period and extraordinary income) at time t; and group * $^{*}$ pred $_{k t}$ is the interaction term between pred ${ }_{k t}$ and the dummy variable for whether a firm is a member of a business group, group ${ }_{k}$. In this model we also include further control variables, firm fixed effects, and year dummies. As Table 9 shows, when one simply nets out the effect of increased energy expenditure as a natural response to an industry shock, the statistical significance of the group-affiliation variable disappears completely.

Thus far we have established three key empirical results. First, the effect on profit of business group affiliation in India is often slightly negative for purely legitimate business reasons, namely that business groups typically take on larger operational costs in response to positive industry shocks than do 
stand-alones. Second, this legitimate negative effect of business group affiliation largely disappears when one applies modern econometric techniques for clustering at the firm level and robust standard errors.

Third, even when the business group affiliation effect is "resuscitated," it quickly disappears when one takes into account the effect of a few logical operational-cost items, notably energy. In the Indian coal-and-lignite industry, two of the biggest players are the stand-alone Gujarat NRE Coke Ltd. and Himadri Chemicals \& Industries Ltd., which belongs to the Himadri Group. Both companies are located in the state of West Bengal, which helps us to control for differences in energy-input price, which in India is set by the state-level electricity-distribution company. In 2002 and 2003 the two companies were quite similar in sales; in 2004, the stand-alone Gujarat NRE experienced a spike in sales (Figure A1).

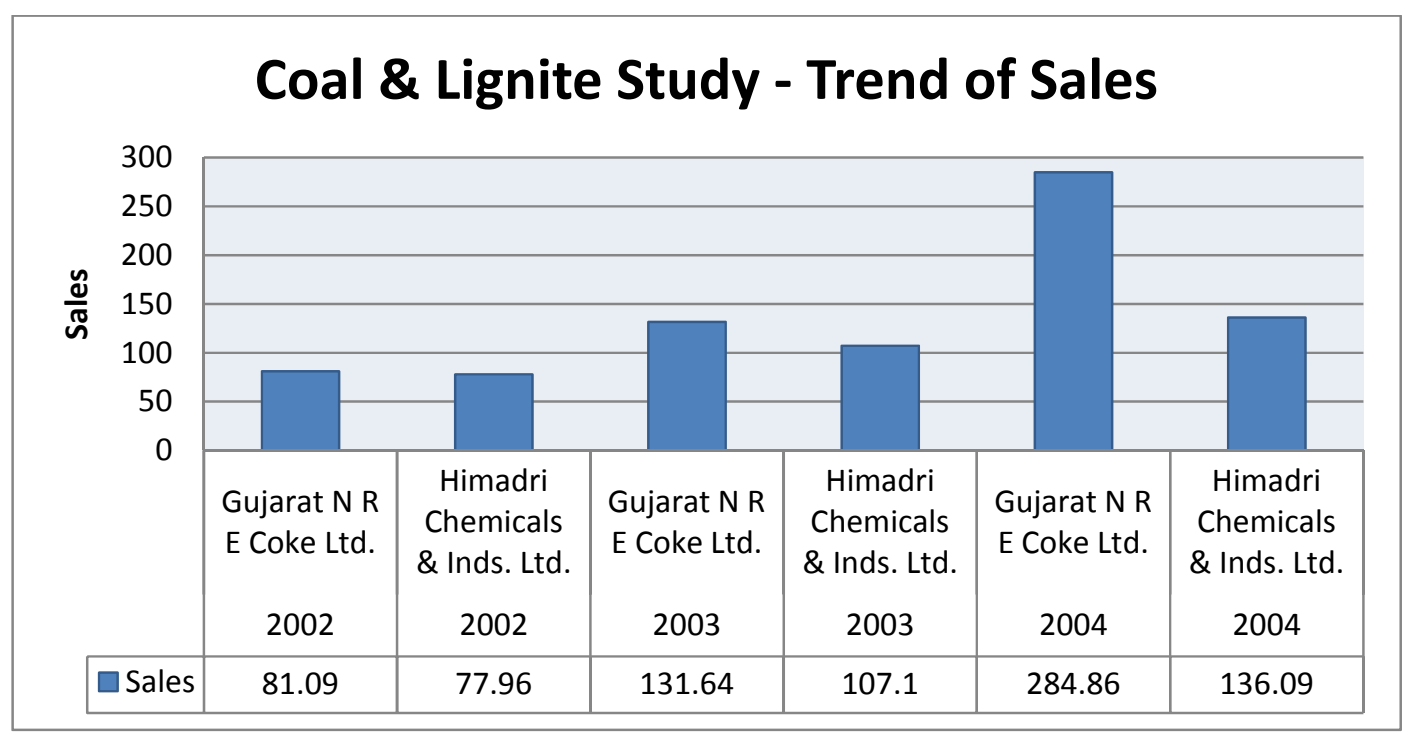

Figure A1. Sales, Gujarat NRE and Himadri

However, even with comparable sales, the stand-alone company exhibits much higher profits, expressed both as PBDITA to Sales and Net Income to Sales. While the stand-alone firm, Gujarat NRE, has a PBDITA-to-sales ratio of $0.17-0.47$, Himadri, the group firm, has a PBDITA-to-sales ratio of only $0.04-0.05$. This is true for each of the three years in consideration when the industry shock was highly positive (Figure A2). Bertrand et al.'s methodology would view this as evidence of tunneling. 


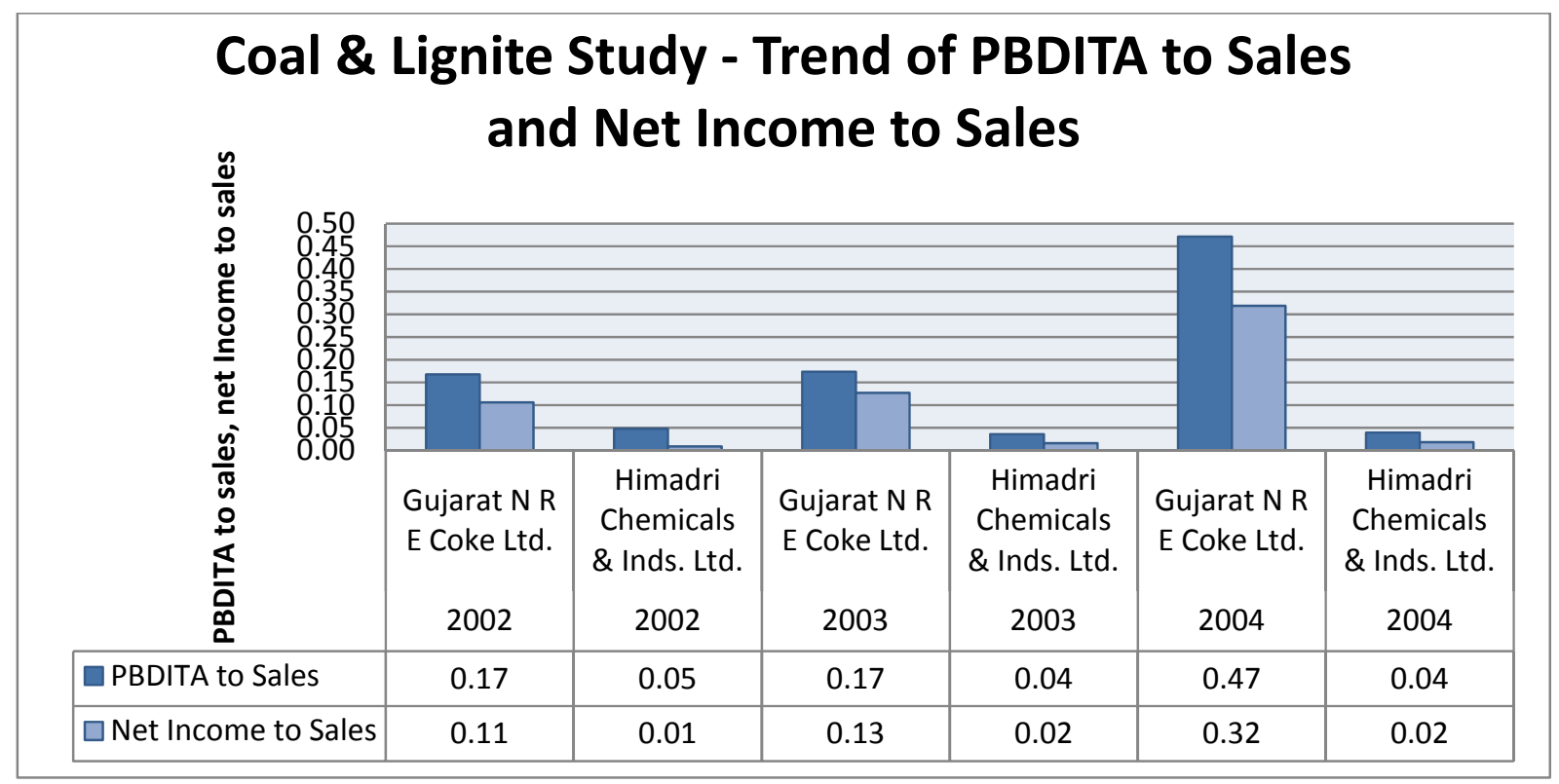

Figure A2. Trend of PBDITA to Sales, Net Income to Sales

Next we looked at the two firm's consumption of raw materials and energy. Their expenses for raw materials are comparable ( 65\%) as a percentage of sales (Figure A3), but energy expenses as a percentage of sales are much higher for the group-affiliated company (Figure A4). The stand-alone firm's fuel cost is $1 \%$ of sales; the group firm's is around $5-7 \%$ of sales. This leads to a paradox: why do two firms that consume raw materials at similar rates differ so markedly in their consumption of energy?

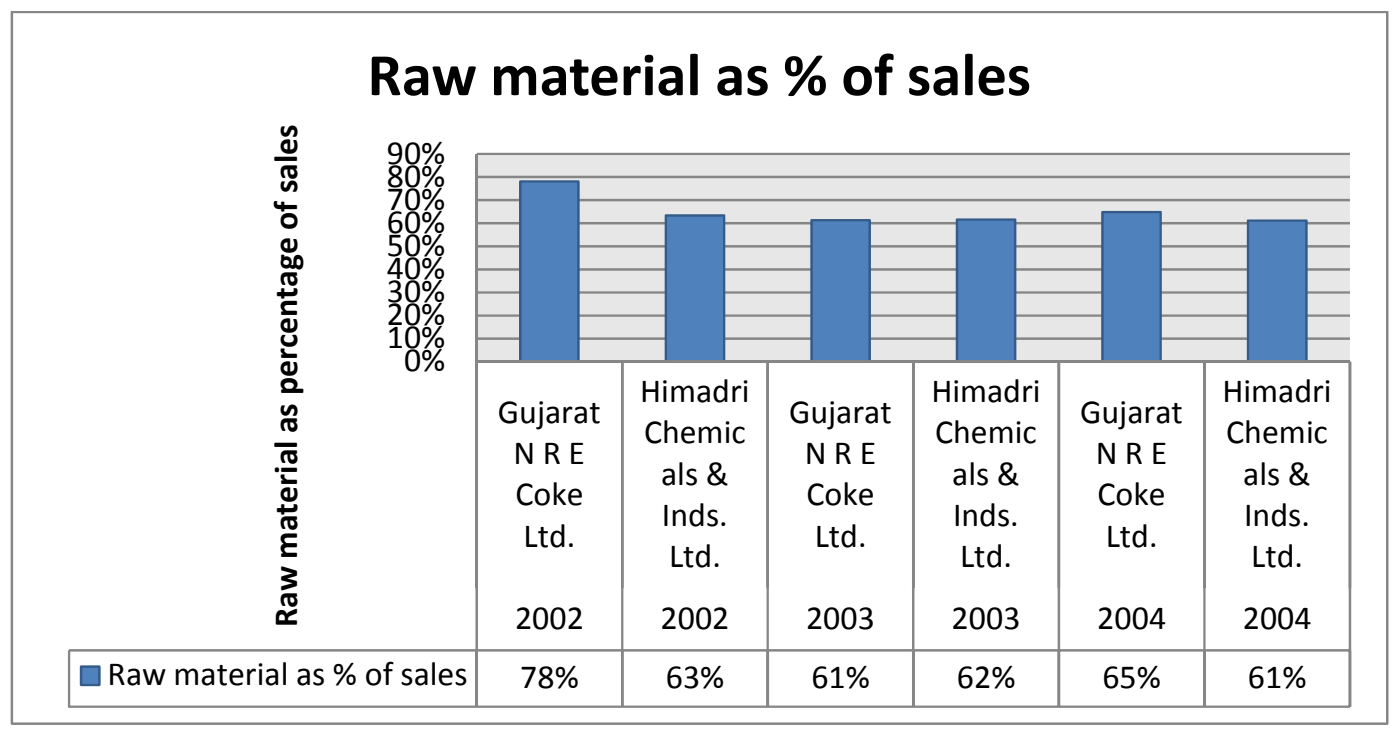

Figure A3. Raw materials as a percentage of sales, Gujarat NRE and Himadri 


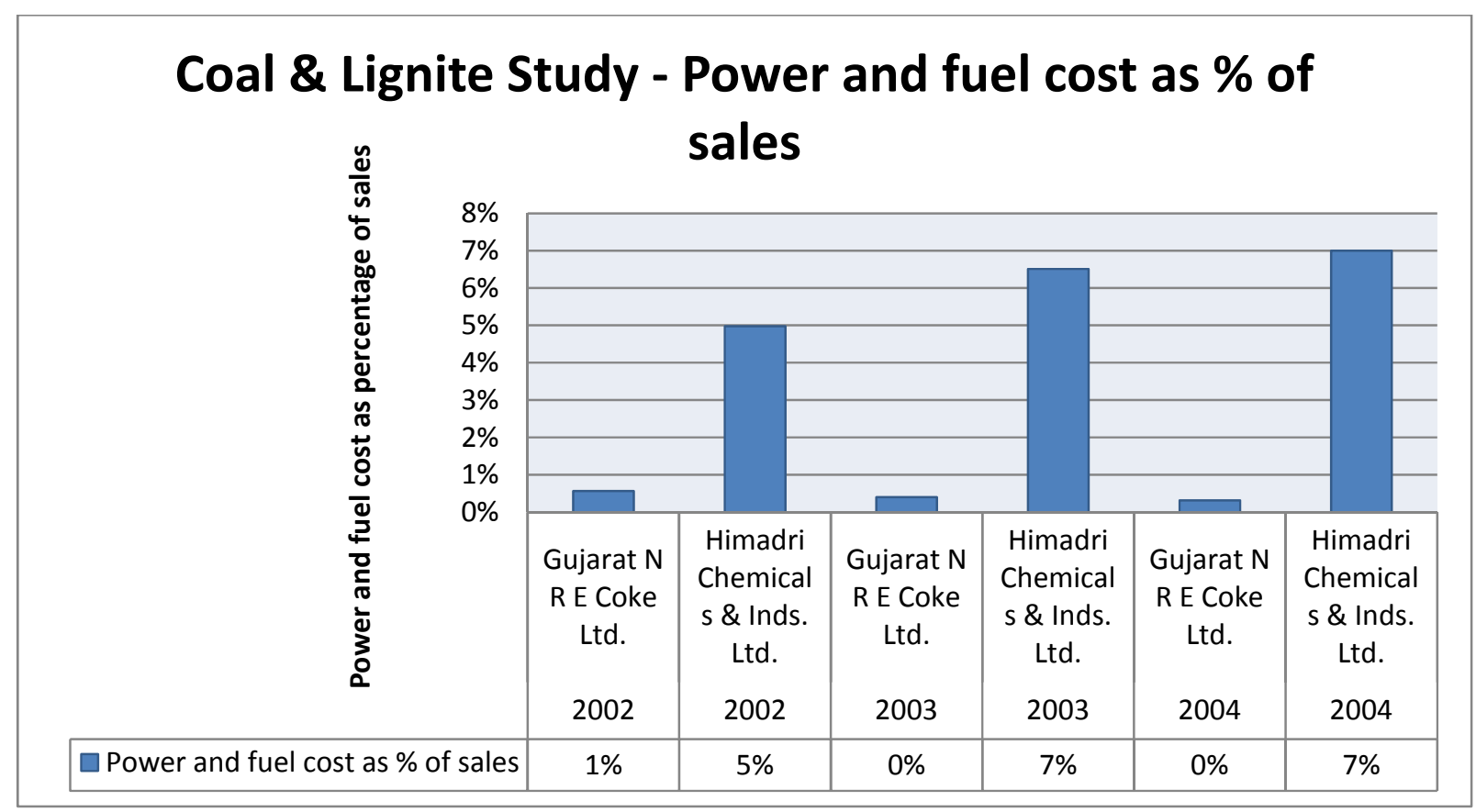

Figure A4. Fuel costs as a percentage of sales, Gujarat NRE and Himadri

The paradox is resolved by looking at the two firms' product mixes. Their annual reports reveal that the stand-alone firm produces only low-ash metallurgical coke; the group-affiliated firm produces a diverse mix of products that includes coal pitch, coal-tar tape, crude naphthalene, dehydrated coal tar, sludge, and "value added oils.” Though both firms are formally classified as belonging to the coal-andlignite industry, the different product mixes suggest significant differences in value-added activities. This leads to differences in fuel/energy costs, which in turn lead to differences in profit.

This example—one of several industry studies we have done as background research for this paper, all of which led to similar findings—is simply meant to show that what we have found through econometrics is no mere statistical artifact; it is confirmable through in-depth, industry-level examinations. Though the above-presented case example is merely illustrative rather than a form of proof, we believe that looking at business groups in terms of their ability through acquired knowledge to do complex recombination of inputs is strongly supported by both small-sample qualitative and largesample quantitative evidence. Given that the literature is primarily oriented toward the latter, we devote most of this study to large-sample quantitative evidence. 
Returning to our large-sample quantitative focus, we perform a series of robustness checks on a set of randomly chosen subsamples and find substantively similar results—-when we focus on the 19891999 period, the 1989-2005 period, the 2001-2008 period, the 2002-2008 period, the 2003-2008 period, or the 1989-2008 period. Interestingly, even when the business group-affiliation effect can be temporarily resuscitated in some of these subsamples, it almost always disappears when we examine the effect of a small set of logical operational activity expenditures for energy, wages, advertising, marketing, and plant repairs, either in isolation or in combination.

We also perform several robustness checks. Whether we use a more aggregate two-digit definition of an industry or a finer-grained four- or five-digit definition, we find substantively similar results. We therefore stick with three-digit codes because the two-digit formulation mixes industries subject together to very different shocks, and the four- and five-digit formulation differentiates firms facing the same shocks, thus eliminating a large percentage of pertinent firms from analysis and compromising the accuracy of the measure of the shocks themselves. In tables to be presented later in which we control for export intensity, the financial sector is omitted; we have confirmed, however, that the business group results are substantively similar if we reinstate the financial sector to those regression tables. We separately find that our results are substantively similar even without the use of clustering. We also find substantively similar results when we artificially constrain the definition of groups to include only relatively large groups of at least $5,10,20,25,30$, or even 50 affiliates. We also find our results to be robust to the further inclusion of advertising intensity, advertising intensity interacted with the shock variable, $R \& D$ intensity, and $R \& D$ intensity interacted with the shock variable. The results are also robust to the inclusion of those variables while omitting the two excise-related variables.

We also wondered whether groups' corporate governance would appear worse if we took into account the effects of changes in price dispersion within an industry; this does not prove to be the case. Using product-pricing data from Prowess, we calculate average product prices for each year in each industry, and then calculate price dispersion as the standard deviation of product prices divided by average product price. We find that price dispersion is not statistically significant in its relationship to 
industry profit shocks, whether defined in terms of PBDITA or of PBDITA/assets and controlling for industry fixed effects and year dummies. Thus it is not the case that branded firms see significantly higher price premiums on average as an effect of profit shocks. Nor is there evidence of a differential group effect during the period 1989-2008 when examining only industries above or below the median in terms of price dispersion. When further controlling for price dispersion, the main group coefficient in the full model is not substantively affected, thus indicating that an omitted variable for price dispersion is not driving the group coefficient.

Next we examine the effect of insider cash-rights ownership and ownership by minority shareholders. As noted earlier, CMIE no longer sells historical ownership data, partly because of the difficulty of staying abreast of changing government-mandated definitions of ownership categories over time, and partly because during much of the period in question firms only disclosed such information when they chose to do so. We therefore affix a big caveat to historical shareholder-ownership analysis, and perform such analysis only to show that we have not neglected to address any of Bertrand et al.'s ownership findings. Thus, with considerable caution, we estimate:

(4) $\operatorname{perf}_{\mathrm{kt}}=\mathrm{a}+\mathrm{b}\left(\operatorname{pred}_{\mathrm{kt}}\right)+\mathrm{c}\left(\operatorname{pred}_{\mathrm{k}} *\right.$ DirectorOwnershipPercentage $\left.\mathrm{kt}_{\mathrm{t}}\right)$

$$
+\mathrm{d}\left(\text { controls }_{\mathrm{kt}}\right)+\text { Firm }_{\mathrm{k}}+\text { Time }_{\mathrm{t}}
$$

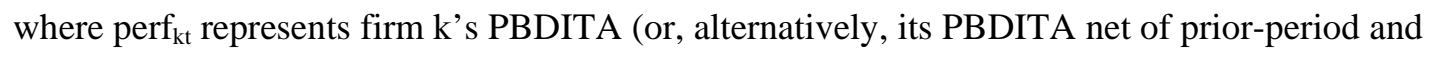
extraordinary income) at time $t$, pred $_{k t}$ is the firm's predicted PBDITA (or, alternatively, its predicted PBDITA net of prior-period and extraordinary income) at time $\mathrm{t}$, and pred $_{\mathrm{kt}}$ * DirectorOwnershipPercentage $\mathrm{kt}_{\mathrm{kt}}$ represents the interaction term between $\operatorname{pred}_{\mathrm{kt}}$ and the percentage of the firm's ownership held by its directors. We also include a set of control variables, firm fixed effects, and year dummies.

Here our results contradict the conventional wisdom. As Table 10 shows, firms actually benefit less from positive industry shocks when they are group-affiliated and their directors possess a lower percentage of cash-right ownership. There is no robust association between minority cash-flow rights and tunneling for group-affiliated firms. It is important to note that ownership data for the 1989-1999 time 
period is largely restricted to the very largest Indian firms, and typically covers just one year for all but a very few firms. Thus such ownership analysis is provided only as a point of comparison with the earlier experiment.

In Table 11 we take a fresh look at Bertrand et al.’s results suggesting that the stock market knew which publicly listed firms were being tunneled and which were receiving funds taken surreptitiously from other firms. Using the most comprehensive data on market-to-book values from a different data source, Capitaline, which focuses on publicly listed firms and collects more detailed capital-market information on those firms, we find results that differ from Bertrand et al.'s. We follow their models in examining whether a given firm's profits are predicted by comparing the firm's Tobin's q to that of the rest of its publicly-traded group affiliates. By contrast to their results, we find no evidence of tunneling per se. Like Bertrand et al., we do find that the firms with the highest valuations in their business groups tend to outperform their peers during a positive industry shock. It surprises us that Bertrand et al. interpreted this finding as a sign of sinister tunneling; the simplest and most logical explanation is that the most skilled firms within a group react the most constructively to positive opportunities. Unlike Bertrand et al., as Table 10 shows, we do not find evidence of firms being systematically affected by other group affiliates’ shocks.

Next we turn our attention to whether groups lost their profit advantage with institutional liberalization. We have already shown that groups systematically pursue more value-added activities and react to shocks with a large increase in the utilization of those value-added activities. Next, what all prior views of business groups, including those from Bertrand et al (2002) and the Strategy literature, predict or imply is that groups will lose much of their competitive advantage with broad improvements in market and governance institutions. Yet, lastly, we find, that the opposite is true in India: groups have, if anything, maintained their advantage or increased their advantage over the two decades of broad-based institutional development. Table 12 shows further that groups maintained a profit edge over stand-alones throughout the entire 1989-2008 period. The institutional voids view of business groups posits that groups' advantage should wither as market institutions develop; we find, on the contrary, that the group 
advantage increased between the advent of liberalization and the end of our study period, by which time market institutions had developed considerably. Though groups' outperformance was indeed largest in the middle of the study period, their outperformance at the end of the time period exceeded that at the beginning. This finding —-that groups' outperformance had not disappeared 19 years after the advent of market liberalization, when market institutions had had nearly two decades to develop and maturedifferentiates our view of business groups from prior views, including those in the strategy literature.

Furthermore, business groups continue to tower over stand-alones in of the magnitude of their investment in both marketing-related and R\&D-related capabilities, as Table 12 also shows. The groupcapabilities multiplier effect, which measures group affiliates' investment in these capabilities per rupee unit of sales divided by stand-alones' investment in these capabilities per rupee unit of sales, is large through the end of the sample. At the end of the period, groups are still investing $42 \%$ more in marketing-related capabilities, and fully 70\% more in R\&D-related capabilities, than stand-alones.

The prevailing view of business groups in the corporate governance literature is that such groups will become obsolete with liberalization and corporate governance reform. Our results suggest, however, that if anything such groups are becoming larger and more diversified over time. As Table 13 shows, the average number of affiliates per business group, and the average number of industries in which a given business group competed, increased significantly between 1989 and 2008.

Nor is it the case that Indian business groups are simply pursuing more and more unrelated diversification over time. As Table 13 shows, the groups encompass more closely related affiliates over time, at least as measured by the average of their average pair-level input-output-table relatedness. Using publicly available Indian data, we can calculate a commercial-dependence index for each portfolio of group affiliates. As a proxy measure for commercial dependence, we (1) translate the industry codes from the 2006-2007 Indian national input-output tables into the ISIC codes used in Prowess, (2) take the inputs and outputs of a given affiliate pair's two industries, (3) compute the percentage of each industry's inputs to and outputs from the other paired industry, (4) take the highest of those four percentages for each affiliate-pair in a given group, (5) take the average of the group's pairs of affiliates, and then (6) take 
the average of that average for all groups in each year. This process generates a country-level relatedness-of-diversification index for Indian business groups for every year between 1989 and 2008. The index serves as a suggestive indicator of whether Indian business groups engaged in increasingly related, or increasingly unrelated, diversification over time. ${ }^{6}$

The finding that Indian business groups increased in size and breadth by embracing more closely related affiliates over time cannot be explained by the views of business groups prevailing in the fields of finance and Strategy, which predict or imply obsolescence when the market and governance institutions mature. Again, we believe that our view of business groups is unique in its ability to explain these results. If groups exist to take advantage of scale-and-scope economies in the production of knowledge, they should only grow in response to economic liberalization and the introduction to the market of more new investors, especially foreign investors, looking for good value-added projects. Given that groups are to a large degree repositories of production skills, they are in a better position than stand-alones to receive outside financial capital and to fund increasingly complex value-added investments related to their existing portfolios.

\section{Discussion}

We believe that the literature on corporate governance needs to be reconceptualized in response to the results of this study. We show here that a thorough understanding of corporate governance requires analysis not merely of governance itself but also of business strategy. The conventional wisdom in the financial literature is that business groups are primarily expropriation devices for their controlling shareholders. $^{7}$ We find that, in India at least, group affiliates tend to pursue systematically different

\footnotetext{
${ }^{6}$ We hope in future research to examine the relatedness of these groups' portfolios of affiliates via Indian patent data citation flows or via occupational demography data within and across industries. Such data are not yet available to academic researchers in India.

${ }^{7}$ Jian and Wong (2010) used a methodology partially based on Bertrand et al. (2002) to examine industry shocks and tunneling in Chinese state-owned firms during the years 1998-2002, but their study did not include firm fixed effects and their sample consisted solely of state-owned firms. Other papers that helped produce the conventional wisdom on tunneling and business groups (e.g., Bae et al. 2002, 2008; Baek et al., 2006) rarely if ever included firm fixed effects and rarely if ever included a comparison reference set of private stand-alones. It is one thing to show that a nontrivial number of business groups commit expropriation and quite another to show that groups on average
} 
business activities than their stand-alone counterparts. Because these business activities tend to be more value-creating, business groups pay significantly higher rates of value-added excise taxes into the public coffers than stand-alones.

Moreover, if such groups indeed take on much higher incremental operational costs to advance their strategic activities in response to positive industry shocks, they should be expected to derive a smaller incremental profit boost than stand-alones, which enjoy the industry shock without the incremental operational costs. As a result, groups should be expected to earn less from the same industry shock, on average, than their stand-alone peers in the same industry. Yet we show that there is no significant difference in the incremental profit outcome between groups and stand-alones.

It is important to emphasize at this point what this study does not aim to do. Specifically, we do not aim to test whether groups are the "good guys" in India. To make such a judgment, one would need to account for more than just how firms treat their outside investors, but also whether they do more or less to corrupt the political process, and whether they do more or less to respect the rights of workers, the environment, and society at large. We simply lack the data to arrive at any such judgment, and the literature we are addressing is focused on the plight of the outside investor. So our study is clearly focused on the relationship between controlling shareholders and outside investors. That said, to be faithful to their outside investors, firms must efficiently utilize their resources, and from a purely efficiency point of view, we do show that groups appear to honestly reflect the effects of macro-level shocks and are investing ever more intensely in the kinds of market activities that investor activities tend to value (technological and marketing capabilities as shown to be an important source of long-term competitive advantage throughout the Strategy literature, and related instead of unrelated diversification as show in both the finance and Strategy literatures).

Importantly, our prediction that business groups will maintain competitive advantage and continue to engage in related diversification after broad-based economic liberalization and enactment of

steal relative to stand-alones. For the latter, Bertrand et al. (2002) continued to stand as of mid-2011 as the state of the art in the literature on tunneling and private-sector business groups. Hopefully, this study has shown that even Bertrand et al.'s incomplete methodology led to incorrect results. 
broad-based corporate governance reforms contradicts the predictions of all prior schools of thought about business groups, including that of Bertrand et al. (2002). The institutional voids thesis holds that business groups are stand-ins for missing market institutions; as those institutions come into being, the competitive advantage of business groups fades. The prevailing hypothesis in the corporate governance literature, including in the influential study by Bertrand et al. (2002), is that business groups exist to function as expropriation devices, and that they will wither as a country embraces the rule of law more vigorously. We believe, on the contrary, that business groups can become larger and more diversified as a country's governmental institutions mature, because the benefits of knowledge agglomeration increase when the institutional infrastructure is stronger and when the pool of middle-class consumers increases and new investors come into India looking for the most talented firms with which to invest.

We should allow, however, for at least the possibility that business groups in India are in fact corruptly manipulative, on average, and that they shrewdly manipulate only operational-cost items to hide their tunneling. Though this is plausible, Occam's Razor suggests that the simplest and most easily supported explanation should be given precedence. The simplest explanation for groups' higher incremental operational costs during a positive industry shock is that those operational activities produce the more sophisticated outputs (and greater profits) they are widely known to be producing in the market.

Our results also suggest that subsequent studies should reexamine the phenomenon of propping, whereby the controlling shareholder secretly injects his or her own funds into the firm; propping is the opposite of tunneling. Friedman, Johnson, and Mitton (2003) provide a compelling law- and financebased argument for why propping might occur. We do not take issue with the logic of their model, but we believe that the extent of propping could be better assessed by determining whether legitimate strategic activities are sometimes mistaken for propping. For example, if Bertrand, Mehta, and Mullainathan’s (2002) results were accurate, their negative business group coefficient would mean that Indian group affiliates typically engage in propping whenever a negative industry shock occurs. But even if the business group coefficient were significantly negative (which it is not, as this study shows), there could be purely legitimate explanations why business groups would experience a negative shock less acutely 
than stand-alone firms. That explanation could well be that, when a negative industry shock occurs, groups can cut back on strategic-activity investments and thus preserve more of their steady-state profit level, whereas stand-alones more dependent on trading finished goods have fewer strategic activity costs to cut back on. Thus, different starting points could lead firms to adjust efficiently in different ways to negative industry shocks. It is important to consider those different starting points and efficiency explanations when conducting corporate governance research.

Further research is also needed on the effect of country differences on business group behavior. Unlike many emerging economies, India has reasonably good governance institutions. Business groups in other emerging economies may or may not play the same value-creating role and may or may not pay significantly higher value-added taxes. We hope this study will spark a new wave of empirical analysis of both country differences and the importance of business strategy in the evaluation of corporate governance.

\section{Conclusion}

In designing our study, we took some inspiration from Williamson (1988), who argued that both efficiency-based arguments and agency-based arguments enhance our understanding of firm behavior, and that given their complementarities, the two sets of arguments should be used jointly. We find it striking that the corporate governance literature has reported so few efforts to control for, and examine, alternative efficiency-based arguments. We thus believe it useful to design a methodology that simultaneously analyzes the efficiency-based arguments of business strategy research and agency-based arguments involving corruption in order to gain greater insight into corporate governance.

The concept of business groups as expropriation devices and as the primary perpetrators of bad governance in emerging economies should be reformulated using more refined empirical methodology that incorporates analysis of strategic activities across firms. We have shown that in India—an important emerging economy—groups have legitimate business reasons not to enjoy positive industry shocks as fully as do stand-alones. Specifically, groups are more likely than stand-alones to pursue value-creating 
recombinative activities that require an increase in costs to respond to an increase in demand and other positive industry shocks. Yet there is no significant difference between groups and stand-alones in the incremental profits they derive from positive industry shocks, perhaps because on average groups are actually governed better than stand-alones. We also find that groups, via their knowledge-based recombinative capabilities, have grown larger and more diversified with market liberalization, and continue to tower over stand-alones in their marketing and technological capabilities. If we are to gain a deeper understanding of the quality of firm-level corporate governance, by taking into account changes in these capabilities and the environments in which groups function, we will need to create stronger links between the widely separated fields of corporate governance and strategy.

\section{References}

Bae, G. S., Y. S. Cheon, and J. K. Kang. 2008. Intragroup Propping: Evidence from the Stock-Price Effects of Earning Announcements by Korean Business Groups. Review of Financial Studies 21: 20152060.

Bae, K. H., J. K. Kang, and J. M. Kim. 2002. Tunneling or Value Added? Evidence from Mergers by Korean Business Groups. Journal of Finance 47: 2695-2740.

Baek, J. S., J. K. Kang, and I. M. Lee. 2006. Business Groups and Tunneling: Evidence from Private Securities Offerings by Korean Chaebols. Journal of Finance 61: 2415-2449.

Bebchuk, L. A., and M. S. Weisbach. 2010. The State of Corporate Governance Research. Review of Financial Studies 23: 939-961.

Bertrand, M., E.Duflo, and S. Mullainathan. 2002. How Much Should We Trust Differences-InDifferences Estimates? National Bureau of Economic Research Working Paper No. 8841.

Bertrand, M., P. Mehta, and S. Mullainathan. 2002. Ferreting Out Tunneling: An Application to Indian Business Groups. Quarterly Journal of Economics 117: 121-148.

Caves, R. E., and M. E. Porter. 1977. From Entry Barriers to Mobility Barriers: Conjectural Decisions and Contrived Deterrence to New Competition. Quarterly Journal of Economics 91: 241-261.

Dharmapala, D., and V. Khanna. 2008. Corporate Governance, Enforcement, and Firm Value: Evidence from India. University of Michigan Law \& Economics, Olin Working Paper 08-005.

Friedman, E., S. Johnson, and T. Mitton. 2003. Propping and Tunneling. Journal of Comparative Economics 31: 732-750. 
Jian, M., and T.J. Wong. 2010. Propping Through Related Party Transactions. Review of Accounting Studies 15: 70-105.

Johnson, S., R. LaPorta, F. Lopez-de-Silanes, and A. Shleifer. 2000. Tunneling. American Economics Review Papers and Proceedings 90: 22-27.

Morck, R., D. Wolfenzon, and B. Yeung. 2005. Corporate Governance, Economic Entrenchment, And Growth. Journal of Economic Literature 43: 657-722.

Porter, M. E. 1980. Competitive Strategy: Techniques for Analyzing Industries and Competitors. New York: Free Press.

Porter, M. E. 1985. Competitive Advantage: Creating and Sustaining Superior Performance. New York: Free Press.

Porter, M. E. 1996. What is Strategy? Harvard Business Review 74: 61-78.

Siegel, J. I. 2005. Can Foreign Firms Bond Themselves Effectively By Renting U.S. Securities Laws? Journal of Financial Economics 75: 319-359.

Williamson, O. E. 1988. Corporate Finance and Corporate Governance. Journal of Finance 43: 567-591. 


\section{Table 1. Summary Statistics}

This table presents summary statistics on our sample, which covers the 1989-2008 time period. We provide means with the standard deviations below them in parenthesis. We start with a column showing the summary statistics for the combined sample of group affiliates and stand-alones. We then show the summary statistics for the groups only. We then present a column of summary statistics for the stand-alones only. To this point, we have excluded foreign-owned and government-owned companies; however, in the last columns we show the summary statistics for the foreign affiliates only and then for the government-owned firms only. For the purposes of a robustness check, we add the foreign-owned firms and government-owned firms to the sample in Tables 8-9.

\section{All financial figures are in Indian Rs. Crore (1 crore = 10 million rupees) and have been converted to 1995 constant currency}

\begin{tabular}{|c|c|c|c|c|c|}
\hline & \multicolumn{3}{|c|}{ Our analyses (1989-2008) } & \multirow[b]{2}{*}{ Foreign Affiliates } & \multirow[b]{2}{*}{ Government-Owned } \\
\hline & All (Group-Affiliated + Stand-alones) & Groups & Stand-alones & & \\
\hline \multirow[t]{2}{*}{ Total assets } & 96.99 & 222.94 & 33.66 & 478.45 & 3253.90 \\
\hline & $(1193.758)$ & $(2026.551)$ & $(254.615)$ & $(2801.388)$ & $(13199.720)$ \\
\hline \multirow[t]{2}{*}{ Total sales } & 55.48 & 123.93 & 21.07 & 171.63 & 868.04 \\
\hline & $(439.866)$ & $(745.372)$ & $(88.916)$ & $(605.846)$ & $(4789.135)$ \\
\hline \multirow[t]{2}{*}{ PBDITA } & 10.51 & 25.11 & 3.17 & 48.92 & 279.21 \\
\hline & $(118.422)$ & $(200.873)$ & $(25.057)$ & $(246.589)$ & $(1063.351)$ \\
\hline \multirow[t]{2}{*}{ Ratio of PBDITA to total assets } & 0.06 & 0.07 & 0.06 & -0.07 & 0.01 \\
\hline & $(1.927)$ & $(2.571)$ & $(1.502)$ & $(12.157)$ & $(1.882)$ \\
\hline \multirow[t]{2}{*}{$\begin{array}{l}\text { Ratio of PBDITA to total assets (with } \\
\text { outliers }<=-0.20 \text { and }>=0.40 \text { temporarily } \\
\text { excluded) }\end{array}$} & 0.08 & 0.09 & 0.07 & 0.11 & 0.08 \\
\hline & $(0.093)$ & $(0.096)$ & $(0.090)$ & $(0.109)$ & $(0.094)$ \\
\hline \multirow[t]{2}{*}{ PBDITA net of NOI and NNRT } & 10.11 & 24.17 & 3.05 & 47.25 & 271.33 \\
\hline & $(117.205)$ & $(198.868)$ & $(24.729)$ & $(242.748)$ & $(1044.745)$ \\
\hline \multirow[t]{2}{*}{$\begin{array}{l}\text { Ratio of (PBDITA net of NOI and } \\
\text { NNRT) to total assets }\end{array}$} & 0.04 & 0.04 & 0.05 & -0.08 & -0.03 \\
\hline & $(1.863)$ & $(3.017)$ & $(0.798)$ & $(12.162)$ & $(1.805)$ \\
\hline \multirow[t]{2}{*}{$\begin{array}{l}\text { Ratio of (PBDITA net of NOI and } \\
\text { NNRT) to total assets (with outliers }<=- \\
0.20 \text { and }>=0.40 \text { temporarily excluded) } \\
\end{array}$} & 0.08 & 0.09 & 0.07 & 0.11 & 0.07 \\
\hline & $(0.092)$ & $(0.097)$ & $(0.090)$ & $(0.108)$ & $(0.093)$ \\
\hline \multirow[t]{2}{*}{\begin{tabular}{|l|} 
Year of incorporation \\
\end{tabular}} & 1981.08 & 1976.44 & 1983.42 & 1976.84 & 1969.09 \\
\hline & $(19.070)$ & $(22.117)$ & $(16.857)$ & $(22.945)$ & $(23.434)$ \\
\hline Sample size with asset size information & 141788 & 47435 & 94353 & 9588 & 7350 \\
\hline
\end{tabular}

Note: The sample size reported above is for firms with asset size information. Yet some firms are missing information on some variables, and therefore the sample size

in the subsequent models will typically be somewhat smaller. 
In this table, we are able to replicate the prior result from Bertrand, Mehta, and Mullainathan (2002), by focusing on either 1989-2008 or 1989-1999, but as they do: without the use of clustering or robust standard errors.

\begin{tabular}{|c|c|c|c|c|c|c|c|c|}
\hline & $\begin{array}{r}\text { Our analys } \\
\text { PBDITA) and } \\
\text { grou }\end{array}$ & $\begin{array}{l}\text { the } 1989 \\
1995 \text { con } \\
\text { liates and }\end{array}$ & $\begin{array}{l}2008 \text { time per } \\
\text { stant rupees an } \\
\text { stand-alone fir }\end{array}$ & $\begin{array}{l}\text { iod (using } \\
\text { d focusing on } \\
\text { rms }\end{array}$ & $\begin{array}{l}\text { Our analys } \\
\text { PBDITA n } \\
\text { constant rup }\end{array}$ & $\begin{array}{l}\text { the 1989-2 } \\
\text { NOI and N } \\
\text { d focusin } \\
\text { tand-alon }\end{array}$ & $\begin{array}{l}2008 \text { time per } \\
\text { NNRT) and us } \\
\text { g on group af } \\
\text { e firms }\end{array}$ & $\begin{array}{l}\text { iod (using } \\
\text { ing } 1995 \\
\text { iiliates and }\end{array}$ \\
\hline & 1 & 2 & 3 & 4 & 1 & 2 & 3 & 4 \\
\hline Own shock & 0.946 & -0.310 & 1.591 & 11.069 & 0.909 & -0.371 & 1.884 & 11.721 \\
\hline & $(0.015)$ & $(0.024)$ & $(0.269)$ & $(0.289)$ & $(0.015)$ & $(0.024)$ & $(0.280)$ & $(0.300)$ \\
\hline \begin{tabular}{|l|} 
Own shock* group \\
\end{tabular} & 0.076 & -0.206 & 0.077 & -0.289 & 0.114 & -0.173 & 0.114 & -0.260 \\
\hline & $(0.015)$ & $(0.015)$ & $(0.015)$ & $(0.015)$ & $(0.015)$ & $(0.015)$ & $(0.015)$ & $(0.015)$ \\
\hline Ln assets & 0.375 & 3.930 & 0.377 & 5.000 & 0.743 & 4.230 & 0.742 & 5.273 \\
\hline & $(0.241)$ & $(0.242)$ & $(0.242)$ & $(0.243)$ & $(0.239)$ & $(0.241)$ & $(0.240)$ & $(0.241)$ \\
\hline Own shock* $\ln$ assets & & 0.137 & & 0.181 & & 0.140 & & 0.185 \\
\hline & & $(0.002)$ & & $(0.002)$ & & $(0.002)$ & & $(0.002)$ \\
\hline \begin{tabular}{|l|} 
Own shock* year of incorporation \\
\end{tabular} & & & $-3.257 \mathrm{E}-04$ & -0.006 & & & $-4.914 \mathrm{E}-04$ & -0.006 \\
\hline & & & $(1.356 \mathrm{E}-04)$ & (1.505E-04) & & & $(1.408 \mathrm{E}-04)$ & $(1.56 \mathrm{E}-04)$ \\
\hline \begin{tabular}{|l|} 
Sample size \\
\end{tabular} & 141039 & 141039 & 140356 & 140356 & 141039 & 141039 & 140356 & 140356 \\
\hline R-squared & 0.500 & 0.518 & 0.500 & 0.524 & 0.494 & 0.512 & 0.494 & 0.519 \\
\hline
\end{tabular}

\begin{tabular}{|c|c|c|c|c|c|c|c|c|}
\hline \multirow{2}{*}{$11 \mathrm{e}$} & \multicolumn{4}{|c|}{$\begin{array}{c}\text { Our analyses for the 1989-1999 time period (using } \\
\text { PBDITA) and using } 1995 \text { constant rupees and focusing on } \\
\text { group affiliates and stand-alone firms }\end{array}$} & \multicolumn{4}{|c|}{$\begin{array}{l}\text { Our analyses for the 1989-1999 time period (using } \\
\text { PBDITA net of NOI and NNRT) and using } 1995 \\
\text { constant rupees and focusing on group affiliates and } \\
\text { stand-alone firms }\end{array}$} \\
\hline & 1 & 2 & 3 & 4 & 1 & 2 & 3 & 4 \\
\hline \multirow[t]{2}{*}{ Own shock } & 0.671 & -2.152 & 31.888 & 18.320 & 0.671 & -2.057 & 32.880 & 19.076 \\
\hline & $(0.024)$ & $(0.034)$ & $(0.602)$ & $(0.554)$ & $(0.024)$ & $(0.034)$ & $(0.595)$ & $(0.557)$ \\
\hline \multirow[t]{2}{*}{ Own shock* group } & 0.136 & -0.291 & 0.167 & -0.240 & 0.125 & -0.301 & 0.160 & -0.243 \\
\hline & $(0.025)$ & $(0.022)$ & $(0.024)$ & $(0.022)$ & $(0.025)$ & $(0.022)$ & $(0.024)$ & $(0.022)$ \\
\hline \multirow[t]{2}{*}{ Ln assets } & 0.664 & 6.385 & 2.147 & 6.945 & 0.756 & 6.230 & 2.272 & 6.765 \\
\hline & $(0.231)$ & $(0.210)$ & $(0.225)$ & $(0.207)$ & $(0.224)$ & $(0.206)$ & $(0.218)$ & $(0.203)$ \\
\hline \multirow[t]{2}{*}{ Own shock* $\ln$ assets } & & 0.333 & & 0.309 & & 0.321 & & 0.294 \\
\hline & & $(0.003)$ & & $(0.003)$ & & $(0.003)$ & & $(0.003)$ \\
\hline \multirow[t]{2}{*}{ Own shock* year of incorporation } & & & -0.016 & -0.010 & & & -0.016 & -0.011 \\
\hline & & & (3.069E-04) & (2.795E-04) & & & $(3.036 \mathrm{E}-04)$ & $(2.808 \mathrm{E}-04)$ \\
\hline Sample size & 47936 & 47936 & 47918 & 47918 & 47936 & 47936 & 47918 & 47918 \\
\hline R-squared & 0.339 & 0.491 & 0.383 & 0.509 & 0.349 & 0.489 & 0.395 & 0.508 \\
\hline
\end{tabular}

Note: In both Panels 1 and 2, the analysis is focused on the group-affiliated firms and stand-alone firms in the Prowess database. Also, in both Panels 1 and 2, the analysis is restricted to industries with two or more firms in a given year. Models included firm fixed effects and year fixed effects. 


\section{Table 3. Heterogeneity In Strategic Activities Between Group-Affiliated Firms and Other Types Of Firms}

This table reports the results from difference of means tests between group-affiliated firms and other types of firms in India.

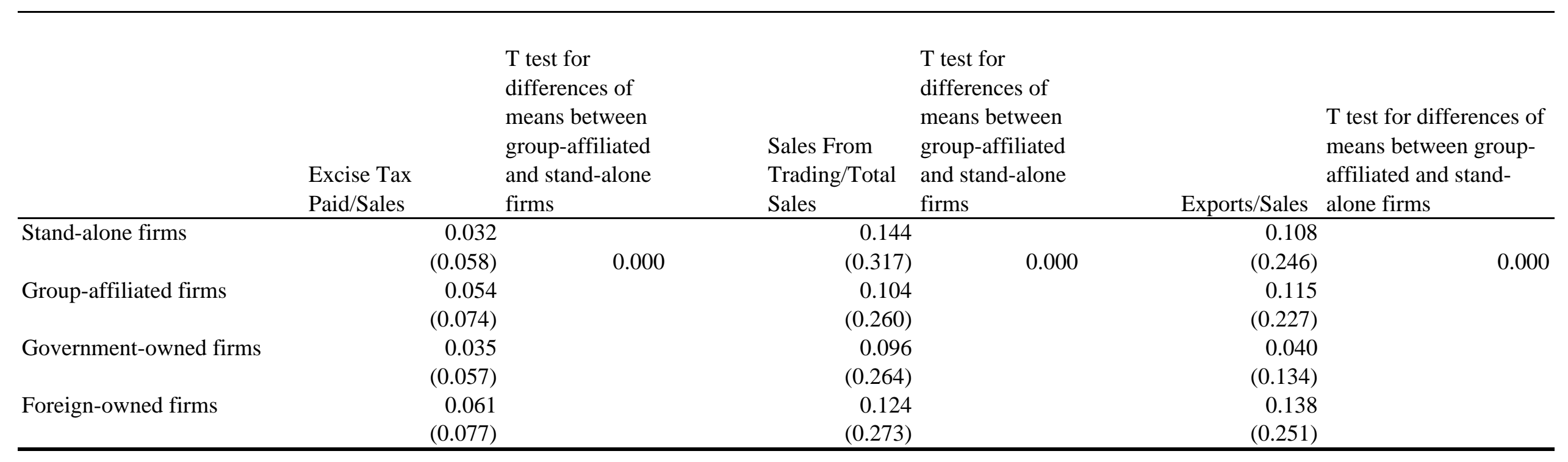


Table 4. How Group-Affiliated Firms and Stand-alone Firms React Differently to Shocks

In this table, we run an illustrative experiment where we are able to see how each strategic activity cost changes when there is an industry shock. Therefore, for the purpose of this very simple illustration, each key operational activity cost is now the alternative dependent variable. We thus estimate: StrategicActivityCostkt $=\mathrm{a}+\mathrm{b}$ (predkt) $+\mathrm{c}$ (lnassetskt) + Firmk + Timet, where StrategicActivityCostkt represents the increase (or decrease) in the magnitude of a firm k's operational activity cost item, including advertising, marketing, distribution, repair and maintenance of plant and machinery, power, fuel, and water costs, etc., at time t, and predkt is the firm's predicted PBDITA (or alternatively its predicted PBDITA net of priorperiod and extraordinary income) at time t. We also control for the log of firm size, firm fixed effects, and year dummies. We run these specifications separately for the groups-only subsample and then for the stand-alones-only sample to get a simple illustration of how these subsamples respond quite differently to industry shocks. What is presented is the regression coefficient for the shock variable (which represents the impact of the shock on that strategic activity cost item for that subsample). Thus, the larger the positive coefficient, the more a positive shock leads to an increase in that strategic activity cost. Conversely, in the case of negative shocks, the larger the coefficient is, the more that strategic activity is reduced, which makes sense since trading-focused stand-alones don't have these same strategic activity costs to cut during a negative shock. Robust standard errors adjusted for clustering at the firm level appear below each coefficient in parenthesis. The industry shock is still being defined by the total population of groups and stand-alones.

\begin{tabular}{|c|c|c|}
\hline & Groups & Stand-alones \\
\hline \multicolumn{3}{|l|}{ Difference in Magnitude: } \\
\hline \multirow[t]{2}{*}{ Advertising } & 0.011 & 0.005 \\
\hline & $(0.002)$ & $(0.001)$ \\
\hline \multirow[t]{2}{*}{ Marketing } & 0.055 & 0.023 \\
\hline & $(0.009)$ & $(0.007)$ \\
\hline $\begin{array}{l}\text { Distribution (for industries with a } \\
\text { minimuml } 1 \% \text { average distribution-to- } \\
\text { sales ratio) }\end{array}$ & $\begin{array}{r}0.071 \\
(0.016)\end{array}$ & $\begin{array}{r}0.071 \\
(0.034)\end{array}$ \\
\hline manufacturing sector) & $\begin{array}{r}0.157 \\
(0.045)\end{array}$ & $\begin{array}{r}0.061 \\
(0.033)\end{array}$ \\
\hline \multirow[t]{2}{*}{$\begin{array}{l}\text { Repairs and maintenance of plant and } \\
\text { machinery (for manufacturing sector) }\end{array}$} & 0.018 & 0.007 \\
\hline & $(0.005)$ & $(0.004)$ \\
\hline \multirow[t]{2}{*}{ Miscellaneous expenditure } & 0.064 & 0.024 \\
\hline & $(0.009)$ & $(0.005)$ \\
\hline \multirow[t]{2}{*}{ Other amortisation } & 0.026 & 0.001 \\
\hline & $(0.009)$ & $(0.001)$ \\
\hline \multirow[t]{2}{*}{ Provisions for bad/doubtful Advances } & 0.071 & 0.022 \\
\hline & $(0.018)$ & $(0.008)$ \\
\hline \multirow[t]{2}{*}{ Total provisions } & 0.078 & 0.024 \\
\hline & $(0.019)$ & $(0.009)$ \\
\hline \multirow[t]{2}{*}{ KwH electricity utilization increase } & 1219744 & 732653.4 \\
\hline & (528603.7) & (226600.3) \\
\hline \multirow{2}{*}{\multicolumn{3}{|c|}{$\begin{array}{l}\text { And It's Not That the Groups Are } \\
\text { Paying Their Executives Much More: }\end{array}$}} \\
\hline & & \\
\hline \multirow[t]{2}{*}{ Directors' remuneration } & 0.001 & 0.001 \\
\hline & (3.396E-04) & $(0.001)$ \\
\hline
\end{tabular}

Note: Robust standard errors clustered at the firm level appear below the coefficients. All models include firm size, year dummies, and firm fixed effects. 
Table 5. Introducing Clustering with Robust Standard Errors

We show in this table that the statistical significance of the business group dummy in the main model of Table 2 in fact goes away when one uses clustering at the firm level with robust standard errors.

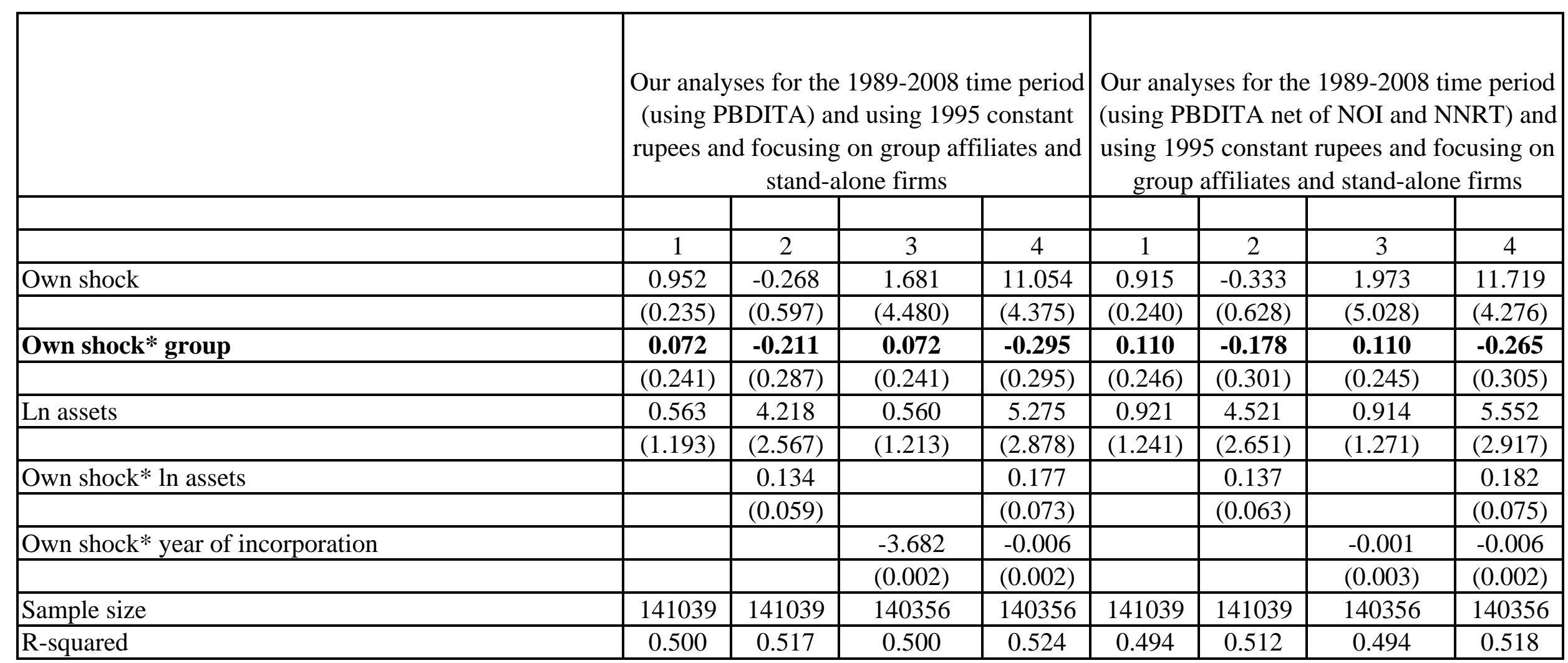

Note: Robust standard errors clustered at the firm level appear below the coefficients. All models include firm fixed

effects and year fixed effects. Firms in an industry containing just one firm are excluded. 
We take the specification from the prior Table 5, which utilized clustering and robust standard errors, and add further control variables related to leverage and export orientation because these time-varying variables could directly impact how firms will react to industry shocks.

\begin{tabular}{|c|c|c|c|c|c|c|c|c|c|c|c|c|c|}
\hline & \multicolumn{4}{|c|}{$\begin{array}{l}\text { Our analyses for the 1989-2008 time period } \\
\text { (using PBDITA) and using } 1995 \text { constant } \\
\text { rupees and focusing on group affiliates and } \\
\text { stand-alone firms }\end{array}$} & \multirow[b]{2}{*}{$\begin{array}{l}\text { plus } \\
\text { marketing- } \\
\text { related }\end{array}$} & \multirow[b]{2}{*}{$\begin{array}{l}\text { plus energy } \\
\quad \text { and } \\
\text { marketing- } \\
\text { related }\end{array}$} & \multicolumn{4}{|c|}{$\begin{array}{l}\text { Our analyses for the 1989-2008 time period } \\
\text { (using PBDITA net of NOI and NNRT) and } \\
\text { using } 1995 \text { constant rupees and focusing on } \\
\text { group affiliates and stand-alone firms }\end{array}$} & \multirow[b]{2}{*}{ plus energy } & \multirow[b]{2}{*}{$\begin{array}{c}\text { plus } \\
\text { marketing- } \\
\text { related }\end{array}$} & \multirow[b]{2}{*}{$\begin{array}{l}\text { plus energy } \\
\text { and } \\
\text { marketing- } \\
\text { related }\end{array}$} \\
\hline & & & & & & & & & & & & & \\
\hline & 1 & 2 & 3 & 4 & 5 & 6 & 1 & 2 & 3 & 4 & 5 & 6 & 7 \\
\hline \multirow[t]{2}{*}{ Own shock } & 0.946 & 1.141 & 1.190 & $\begin{array}{l}-8.755 \\
\end{array}$ & $\begin{array}{l}-12.531 \\
\end{array}$ & -14.244 & 0.909 & 1.099 & 1.169 & -7.068 & -8.517 & -11.070 & -12.519 \\
\hline & (0.238) & $(0.229)$ & $(0.244)$ & (7.988) & (8.471) & (8.966) & $(0.242)$ & $(0.241)$ & $(0.231)$ & $(7.922)$ & (8.529) & (8.441) & $\begin{array}{l}(9.000) \\
\end{array}$ \\
\hline \multirow{2}{*}{ Own shock* group } & 0.076 & 0.132 & -0.278 & -0.435 & -0.372 & -0.272 & 0.114 & 0.181 & -0.265 & -0.418 & -0.319 & -0.353 & -0.254 \\
\hline & $(0.243)$ & $(0.213)$ & $(0.256)$ & $(0.220)$ & $(0.233)$ & $(0.253)$ & $(0.247)$ & $(0.226)$ & $(0.248)$ & $(0.237)$ & $(0.258)$ & $(0.251)$ & $(0.272)$ \\
\hline \multirow[t]{2}{*}{ Ln assets } & 0.375 & 1.011 & 1.984 & 13.515 & 14.504 & 15.654 & 0.743 & 1.388 & 2.598 & 13.701 & 14.961 & 14.742 & 16.001 \\
\hline & (1.091) & $(1.160)$ & (2.393) & $(8.080)$ & (8.239) & (8.741) & $(1.136)$ & (1.209) & (2.569) & $(8.062)$ & (8.587) & $(8.230)$ & $(8.755)$ \\
\hline \multirow[t]{2}{*}{ Own shock* ln assets } & & & & 0.463 & 0.477 & 0.484 & & & & 0.463 & 0.472 & 0.479 & 0.488 \\
\hline & & & & $(0.241)$ & $(0.246)$ & $(0.259)$ & & & & $(0.243)$ & (0.258) & (0.249) & $(0.263)$ \\
\hline \multirow[t]{2}{*}{ Own shock* year of incorporation } & & & & 0.003 & 0.005 & 0.006 & & & & 0.002 & 0.003 & 0.004 & 0.005 \\
\hline & & & & $(0.003)$ & $(0.004)$ & $(0.004)$ & & & & $(0.003)$ & $(0.004)$ & $(0.004)$ & $(0.004)$ \\
\hline \multirow[t]{2}{*}{ Leverage } & & 0.006 & & 0.881 & 0.936 & 0.995 & & 0.011 & & 0.911 & 0.976 & 0.968 & 1.033 \\
\hline & & $(0.011)$ & & $(0.558)$ & $(0.573)$ & $(0.607)$ & & $(0.013)$ & & $(0.557)$ & $(0.593)$ & $(0.573)$ & $(0.609)$ \\
\hline \multirow[t]{2}{*}{ Own shock* leverage } & & $\begin{array}{l}-0.889 \\
\end{array}$ & & $\begin{array}{l}-1.832 \\
\end{array}$ & -1.922 & -2.006 & & -0.914 & & -1.837 & -1.929 & -1.931 & -2.024 \\
\hline & & $\begin{array}{l}(0.371) \\
\end{array}$ & & $(0.646)$ & $(0.662)$ & $(0.702)$ & & $\begin{array}{l}(0.395) \\
\end{array}$ & & $(0.650)$ & $(0.690)$ & $(0.667)$ & $(0.710)$ \\
\hline \multirow[t]{2}{*}{ Export orientation } & & & 0.281 & 0.247 & 0.295 & 0.345 & & & 0.249 & 0.217 & 0.265 & 0.265 & 0.313 \\
\hline & & & $(0.320)$ & $(0.288)$ & (0.326) & (0.373) & & & $(0.311)$ & $(0.276)$ & (0.321) & (0.314) & (0.359) \\
\hline \multirow[t]{2}{*}{ Own shock* export orientation } & & & -0.001 & -0.001 & -0.001 & -0.001 & & & -0.001 & -0.001 & -0.001 & -0.001 & -0.001 \\
\hline & & & $(0.002)$ & $(0.001)$ & $(0.002)$ & $(0.002)$ & & & $(0.002)$ & $(0.001)$ & $(0.002)$ & $(0.002)$ & $(0.002)$ \\
\hline \begin{tabular}{|l|} 
Sample size \\
\end{tabular} & 141039 & 141039 & 105511 & 105090 & 105090 & 105090 & 141039 & 141039 & 105511 & 105090 & 105090 & 105090 & 105090 \\
\hline R-squared & 0.500 & 0.519 & 0.240 & 0.324 & 0.337 & 0.344 & 0.494 & 0.514 & 0.228 & 0.307 & 0.316 & 0.320 & 0.329 \\
\hline
\end{tabular}

Note that the sample size is smaller when export orientation is included because the variable is not available for all firms.

Note: Robust standard errors clustered at the firm level appear below the coefficients. All models include firm fixed effects and year fixed effects.

Firms in an industry containing just one firm are excluded. 
We take the specification from the prior Table 6, which utilized clustering and robust standard errors, and add yet further control variables related to trading emphasis and value-added recombination emphasis as proxied by the firm's ratio of excise taxes paid/total sales, since these time-varying variables may directly impact how firms will react to industry shocks.

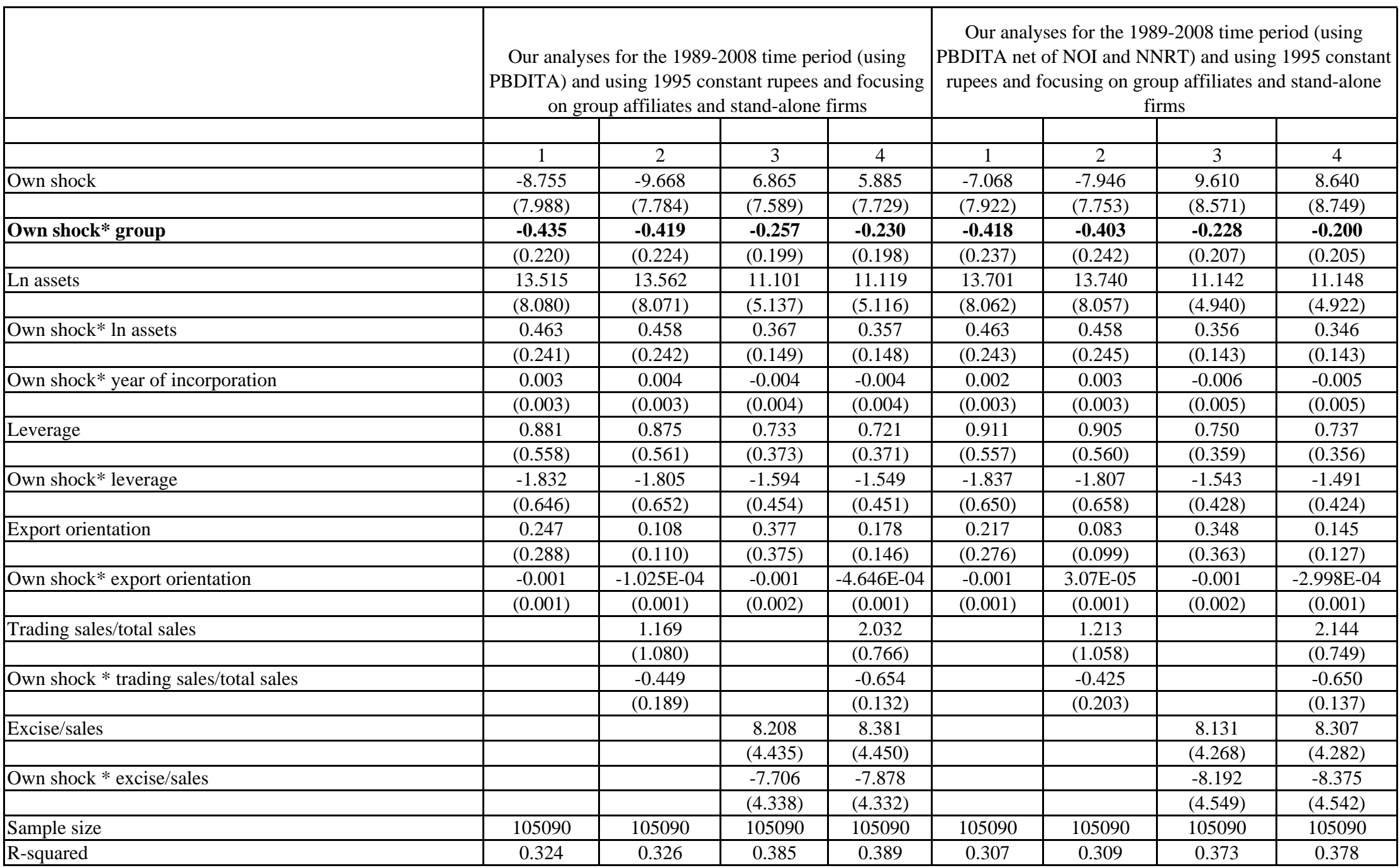

Note: Robust standard errors clustered at the firm level appear below the coefficients. All models include firm fixed effects and year fixed

effects. Firms in an industry containing just one firm are excluded. 
In this table, we take the basic specification from the prior Table 5, which included clustering and robust standard errors, and we now add foreign-owned firms and government-owned firms to the sample for the purpose of a robustness check.

\begin{tabular}{|c|c|c|c|c|c|c|c|c|}
\hline & \multicolumn{4}{|c|}{\begin{tabular}{|c|} 
Our analyses for the 1989-2008 time \\
period (using PBDITA) and using 1995 \\
constant rupees and including both \\
foreign-owned firms and government- \\
owned firms
\end{tabular}} & \multicolumn{4}{|c|}{$\begin{array}{c}\text { Our analyses for the } 1989-2008 \text { time } \\
\text { period (using PBDITA net of NOI and } \\
\text { NNRT) and using } 1995 \text { constant rupees } \\
\text { and including both foreign-owned } \\
\text { firms and government-owned firms } \\
\end{array}$} \\
\hline & & & & & & & & \\
\hline & 1 & 2 & 3 & 4 & 1 & 2 & 3 & 4 \\
\hline \multirow[t]{2}{*}{ Own shock } & 1.057 & -0.083 & 6.432 & 5.745 & 0.454 & -0.373 & 4.482 & 4.224 \\
\hline & $(0.184)$ & $(0.501)$ & $(3.391)$ & $(3.125)$ & $(0.555)$ & $(0.697)$ & $(3.601)$ & $(3.454)$ \\
\hline \multirow[t]{2}{*}{ Own shock* group } & 0.077 & -0.190 & 0.075 & -0.196 & 0.689 & 0.441 & 0.688 & 0.434 \\
\hline & (0.195) & $(0.221)$ & $(0.197)$ & $(0.221)$ & $(0.558)$ & $(0.497)$ & $(0.559)$ & $(0.499)$ \\
\hline \multirow[t]{2}{*}{ Own shock * foreign-owned } & -0.105 & -0.258 & -0.170 & -0.331 & 0.480 & 0.320 & 0.432 & 0.261 \\
\hline & (0.195) & (0.208) & (0.201) & (0.215) & (0.558) & (0.508) & (0.568) & $(0.520)$ \\
\hline \multirow[t]{2}{*}{ Own shock * government-owned } & -0.197 & -0.552 & -0.266 & -0.632 & 0.490 & 0.162 & 0.437 & 0.094 \\
\hline & $(0.195)$ & $(0.253)$ & $(0.207)$ & $(0.264)$ & $(0.578)$ & $(0.518)$ & $(0.593)$ & $(0.536)$ \\
\hline \multirow[t]{2}{*}{ Ln assets } & -0.857 & 3.422 & -0.685 & 3.689 & 0.470 & 3.557 & 0.598 & 3.779 \\
\hline & $(0.667)$ & $(2.004)$ & $(0.688)$ & $(2.010)$ & $(1.245)$ & $(1.842)$ & $(1.230)$ & $(1.848)$ \\
\hline \multirow[t]{2}{*}{ Own shock* $\ln$ assets } & & 0.126 & & 0.128 & & 0.096 & & 0.098 \\
\hline & & $(0.051)$ & & $(0.050)$ & & $(0.032)$ & & $(0.032)$ \\
\hline \multirow[t]{2}{*}{ Own shock* year of incorporation } & & & -0.003 & -0.003 & & & -0.002 & -0.002 \\
\hline & & & $(0.002)$ & $(0.002)$ & & & $(0.002)$ & $(0.002)$ \\
\hline Sample size & 158522 & 158522 & 157600 & |157600 & 158498 & 158498 & 157576 & 157576 \\
\hline R-squared & 0.642 & 0.663 & 0.645 & 0.667 & 0.674 & 0.685 & 0.676 & 0.687 \\
\hline
\end{tabular}

Note: Robust standard errors clustered at the firm level appear below the coefficients. All models include firm fixed

effects and year fixed effects. Firms in an industry containing just one firm are excluded. 
In this table, we take the specification from the prior Table 8, and then add control variables related to leverage, export orientation, trading emphasis, and value-added recombination emphasis as proxied by the ratio of excise taxes paid/total sales.

\begin{tabular}{|c|c|c|c|c|c|c|c|c|c|c|}
\hline & \multicolumn{4}{|c|}{$\begin{array}{l}\text { Our analyses for the } 1989-2008 \text { time period (using } \\
\text { PBDITA) and using } 1995 \text { constant rupees and including } \\
\text { both foreign-owned firms and government-owned firms }\end{array}$} & \multicolumn{5}{|c|}{$\begin{array}{c}\text { Our analyses for the 1989-2008 time period (using } \\
\text { PBDITA net of NOI and NNRT) and using } 1995 \\
\text { constant rupees and including both foreign-owned firms } \\
\text { and government-owned firms }\end{array}$} & \multirow{2}{*}{ plus energy } \\
\hline & & & & & plus energy & & & & & \\
\hline & 1 & 2 & 3 & 4 & 5 & 1 & 2 & 3 & 4 & 5 \\
\hline \multirow[t]{2}{*}{ Own shock } & 0.199 & 0.159 & 4.564 & 4.509 & 3.458 & 1.794 & 1.778 & 5.836 & 5.828 & 4.858 \\
\hline & $(10.744)$ & $(10.702)$ & $(10.690)$ & (10.644) & (10.909) & (11.113) & (11.095) & $(10.841)$ & (10.817) & (11.125) \\
\hline \multirow[t]{2}{*}{\begin{tabular}{|l|} 
Own shock* group \\
\end{tabular}} & -0.308 & -0.302 & -0.311 & -0.306 & -0.217 & -0.282 & -0.281 & -0.282 & -0.282 & -0.190 \\
\hline & $(0.147)$ & $(0.144)$ & $(0.149)$ & $(0.146)$ & $(0.152)$ & $(0.151)$ & $(0.149)$ & $(0.153)$ & $(0.151)$ & $(0.158)$ \\
\hline \multirow[t]{2}{*}{ Own shock * foreign-owned } & -0.263 & -0.265 & -0.152 & -0.154 & -0.078 & -0.289 & -0.289 & -0.190 & -0.190 & -0.147 \\
\hline & $\begin{array}{l}(0.133) \\
\end{array}$ & $\begin{array}{l}(0.133) \\
\end{array}$ & (0.156) & (0.156) & (0.209) & $(0.133)$ & $\begin{array}{l}(0.133) \\
\end{array}$ & $\begin{array}{l}(0.166) \\
\end{array}$ & $\begin{array}{l}(0.166) \\
\end{array}$ & $(0.247)$ \\
\hline \multirow{2}{*}{ Own shock * government-owned } & -0.999 & -0.996 & -0.958 & -0.956 & -0.969 & -0.952 & -0.952 & -0.921 & -0.921 & -0.941 \\
\hline & $(0.244)$ & $(0.239)$ & $(0.241)$ & $(0.237)$ & $(0.239)$ & $(0.265)$ & $(0.264)$ & $(0.259)$ & $(0.258)$ & $(0.261)$ \\
\hline \multirow[t]{2}{*}{ Ln assets } & 8.240 & 8.022 & 7.922 & 7.756 & 8.343 & 7.999 & 7.935 & 7.817 & 7.778 & 8.585 \\
\hline & (2.683) & $(2.455)$ & (2.663) & (2.438) & (2.499) & $(2.711)$ & $(2.547)$ & $(2.685)$ & $(2.521)$ & $(2.585)$ \\
\hline \multirow[t]{2}{*}{\begin{tabular}{|l|} 
Own shock* $\ln$ assets \\
\end{tabular}} & 0.230 & 0.228 & 0.222 & 0.221 & 0.206 & 0.222 & 0.221 & 0.216 & 0.215 & 0.202 \\
\hline & (0.059) & $(0.057)$ & (0.060) & $\begin{array}{l}(0.058) \\
\end{array}$ & $\begin{array}{l}(0.058) \\
\end{array}$ & $(0.064)$ & $(0.062)$ & $(0.064)$ & (0.063) & $(0.062)$ \\
\hline \multirow[t]{2}{*}{ Own shock* year of incorporation } & $-3.453 \mathrm{E}-04$ & $-3.218 \mathrm{E}-04$ & -0.003 & -0.002 & -0.002 & -0.001 & -0.001 & -0.003 & -0.003 & -0.003 \\
\hline & (0.005) & $\begin{array}{l}(0.005) \\
\end{array}$ & (0.005) & (0.005) & (0.005) & (0.006) & $\begin{array}{l}(0.006) \\
\end{array}$ & $(0.005)$ & (0.005) & $(0.006)$ \\
\hline \multirow[t]{2}{*}{ Leverage } & 0.436 & 0.428 & 0.394 & 0.389 & 0.373 & 0.421 & 0.421 & 0.396 & 0.398 & 0.391 \\
\hline & $(0.164)$ & $(0.150)$ & (0.143) & (0.131) & $(0.132)$ & $(0.159)$ & $(0.150)$ & $(0.140)$ & $\begin{array}{l}(0.133) \\
\end{array}$ & $(0.135)$ \\
\hline \multirow[t]{2}{*}{ Own shock* leverage } & -1.543 & -1.533 & -1.400 & -1.394 & -1.491 & -1.380 & -1.378 & -1.282 & -1.281 & -1.395 \\
\hline & $\begin{array}{l}(0.334) \\
\end{array}$ & $(0.320)$ & $(0.281)$ & $\begin{array}{l}(0.273) \\
\end{array}$ & $(0.273)$ & $(0.339)$ & $\begin{array}{l}(0.333) \\
\end{array}$ & $(0.281)$ & $\begin{array}{l}(0.279) \\
\end{array}$ & $(0.279)$ \\
\hline \multirow[t]{2}{*}{\begin{tabular}{|l|} 
Export orientation \\
\end{tabular}} & 0.100 & 0.149 & 0.127 & 0.164 & 0.172 & 0.092 & 0.104 & 0.118 & 0.123 & 0.129 \\
\hline & $(0.232)$ & $(0.247)$ & $(0.237)$ & $(0.244)$ & $(0.256)$ & $(0.232)$ & $(0.218)$ & $(0.236)$ & $(0.218)$ & $(0.229)$ \\
\hline \multirow[t]{2}{*}{ Own shock* export orientation } & $-6.37 \mathrm{E}-05$ & $-3.743 \mathrm{E}-04$ & $-2.36 \mathrm{E}-04$ & $-4.632 \mathrm{E}-04$ & -0.001 & $-1.72 \mathrm{E}-05$ & $-9.43 \mathrm{E}-05$ & $-1.83 \mathrm{E}-04$ & $-2.131 \mathrm{E}-04$ & $-2.526 \mathrm{E}-04$ \\
\hline & $\begin{array}{l}(0.001) \\
\end{array}$ & $(0.002)$ & (0.001) & $(0.002)$ & (0.002) & $\begin{array}{l}(0.001) \\
\end{array}$ & $\begin{array}{l}(0.001) \\
\end{array}$ & $\begin{array}{l}0.002) \\
\end{array}$ & $\begin{array}{l}(0.001) \\
\end{array}$ & (0.001) \\
\hline \multirow[t]{2}{*}{ Trading sales/total sales } & & -3.427 & & -3.244 & -3.688 & & -2.255 & & -2.251 & -2.716 \\
\hline & & (2.311) & & (2.376) & (2.419) & & $(2.046)$ & & (2.172) & $(2.225)$ \\
\hline \multirow[t]{2}{*}{ Own shock * trading sales/total sales } & & 0.157 & & 0.115 & 0.022 & & 0.038 & & 0.014 & -0.079 \\
\hline & & $(0.284)$ & & $(0.289)$ & $(0.290)$ & & $(0.258)$ & & $(0.268)$ & $(0.269)$ \\
\hline \multirow[t]{2}{*}{ Excise/sales } & & & 2.361 & 2.306 & 2.064 & & & 2.093 & 2.044 & 1.635 \\
\hline & & & (0.956) & (0.933) & (1.046) & & & $(1.217)$ & (1.204) & (1.414) \\
\hline \multirow[t]{2}{*}{ Own shock * excise/sales } & & & -1.363 & -1.355 & -1.221 & & & -1.396 & -1.395 & -1.174 \\
\hline & & & $(0.408)$ & $(0.406)$ & $(0.475)$ & & & $(0.651)$ & $(0.645)$ & $(0.804)$ \\
\hline \begin{tabular}{|l|} 
Sample size \\
\end{tabular} & 118432 & 118432 & 118432 & 118432 & 118432 & 118432 & 118432 & 118432 & 118432 & 118432 \\
\hline R-squared & 0.616 & 0.617 & 0.626 & 0.626 & 0.625 & 0.618 & 0.618 & 0.624 & 0.624 & 0.624 \\
\hline
\end{tabular}

Note: Robust standard errors clustered at the firm level appear below the coefficients. All models include firm fixed effects and year

fixed effects. Firms in an industry containing just one firm are excluded. 
This table is simply meant to show that the available ownership data from India from the 1990s was quite limited and that the results even for this limited available sample of (typically) the largest firms do not match with prevailing conventional wisdom.

\section{Panel A: Director Equity}

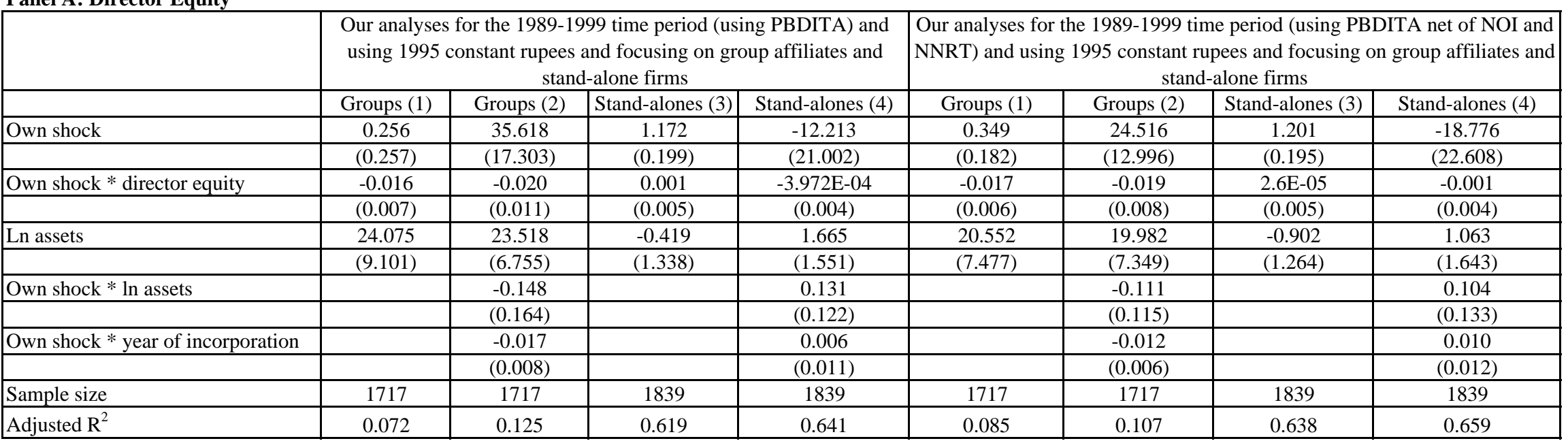

\section{Panel B: Other Ownership}

\begin{tabular}{|c|c|c|c|c|c|c|c|c|}
\hline & \multicolumn{4}{|c|}{$\begin{array}{l}\text { Our analyses for the } 1989-1999 \text { time period (using PBDIT) and } \\
\text { using } 1995 \text { constant rupees and focusing on group affiliates and } \\
\text { stand-alone firms }\end{array}$} & \multicolumn{4}{|c|}{$\begin{array}{l}\text { Our analyses for the 1989-1999 time period (using PBDIT net of NOI and } \\
\text { NNRT) and using } 1995 \text { constant rupees and focusing on group affiliates and } \\
\text { stand-alone firms }\end{array}$} \\
\hline & Groups (1) & Groups (2) & Stand-alones (3) & Stand-alones (4) & Groups (1) & Groups (2) & Stand-alones (3) & Stand-alones (4) \\
\hline \multirow[t]{2}{*}{ Own shock } & 0.412 & 34.219 & 0.975 & -20.631 & 0.459 & 23.295 & 0.987 & -27.099 \\
\hline & $(0.298)$ & $(17.371)$ & $(0.187)$ & $(19.431)$ & $(0.212)$ & $(12.940)$ & $(0.168)$ & $(21.152)$ \\
\hline \multirow[t]{2}{*}{ Own shock * other ownership } & -0.006 & -0.005 & 0.009 & 0.011 & -0.004 & -0.004 & 0.009 & 0.011 \\
\hline & $(0.004)$ & $(0.004)$ & $(0.004)$ & $(0.004)$ & $(0.003)$ & $(0.003)$ & $(0.004)$ & $(0.004)$ \\
\hline \multirow[t]{2}{*}{ Ln assets } & 22.359 & 22.455 & -0.523 & 1.575 & 18.969 & 19.071 & -1.023 & 0.942 \\
\hline & $(8.822)$ & $(6.733)$ & $(1.332)$ & $(1.492)$ & $(7.170)$ & $(7.386)$ & $(1.256)$ & $(1.591)$ \\
\hline \multirow[t]{2}{*}{ Own shock * $\ln$ assets } & & -0.116 & & 0.116 & & -0.080 & & 0.088 \\
\hline & & $(0.154)$ & & $(0.112)$ & & $(0.113)$ & & $(0.124)$ \\
\hline \multirow[t]{2}{*}{ Own shock * year of incorporation } & & -0.017 & & 0.010 & & -0.011 & & 0.014 \\
\hline & & $(0.008)$ & & $(0.010)$ & & $(0.006)$ & & $(0.011)$ \\
\hline Sample size & 1717 & 1717 & 1839 & 1839 & 1717 & 1717 & 1839 & 1839 \\
\hline R-squared & 0.081 & 0.126 & 0.632 & 0.658 & 0.088 & 0.105 & 0.652 & 0.677 \\
\hline
\end{tabular}

Note: Robust standard errors clustered at the firm level appear below the coefficients. All models include firm fixed effects and year fixed

effects. Firms in an industry containing just one firm are excluded. 
In this table, we take a fresh look at Bertrand et al.’s results suggesting that the stock market knew which firms were being tunneled and which were receiving funds taken surreptitiously from other firms. Using the most comprehensive data on market to book values from a separate data source, Capitaline, which focuses on publicly listed firms and collects yet more detailed capital market information on those publicly firms, we find different results from what was found in the prior study. We follow their models in seeing if the firm's profits are predicted by whether the firm's Tobin's q is high relative to the rest of its publicly-traded group affiliates. In contrast to their results, we don't find any evidence of tunneling per se. Like Bertrand et al., we do find that firms that have the highest valuations in their business groups tend to outperform their peers in a positive industry shock. We find it surprising that Bertrand et al. interpreted this as a sign of sinister tunneling, whereas by Occam's Razor, the simplest and most logical explanation is that the most skilled firms within a group are the ones that react the most constructively to positive opportunities.

\begin{tabular}{|c|c|c|c|c|c|c|c|c|}
\hline & \multicolumn{4}{|c|}{$\begin{array}{l}\text { Our analyses for the 1989-2008 time period (using } \\
\text { PBDITA) and using } 1995 \text { constant rupees }\end{array}$} & \multicolumn{4}{|c|}{$\begin{array}{l}\text { Our analyses for the 1989-1999 time period } \\
\text { (using PBDITA net of NOI and NNRT) and } \\
\text { using } 1995 \text { constant rupees }\end{array}$} \\
\hline & $(1)$ & $(2)$ & (3) & (4) & $(1)$ & $(2)$ & (3) & (4) \\
\hline \multirow[t]{2}{*}{ Own shock } & 1.015 & 1.025 & 0.998 & 1.021 & 1.038 & 1.025 & 1.006 & 1.045 \\
\hline & $(0.148)$ & $(0.074)$ & $(0.158)$ & $(0.145)$ & $(0.159)$ & $(0.080)$ & $(0.174)$ & $(0.158)$ \\
\hline \multirow[t]{2}{*}{ Own shock * firm Q } & 0.001 & & & 0.016 & 0.010 & & & 0.026 \\
\hline & $(0.054)$ & & & $(0.065)$ & $(0.059)$ & & & $(0.080)$ \\
\hline \multirow[t]{2}{*}{ Own shock * relative Q } & & 0.105 & & & & 0.119 & & \\
\hline & & $(0.044)$ & & & & $(0.045)$ & & \\
\hline \multirow[t]{2}{*}{ Own shock * group Q } & & & -0.014 & -0.021 & & & -0.010 & -0.022 \\
\hline & & & $(0.067)$ & $(0.083)$ & & & $(0.072)$ & $(0.094)$ \\
\hline \multirow[t]{2}{*}{ Group shock } & 0.008 & 0.013 & 0.028 & 0.026 & 0.009 & 0.015 & 0.029 & 0.026 \\
\hline & $(0.009)$ & $(0.012)$ & $(0.041)$ & $(0.039)$ & $(0.009)$ & $(0.013)$ & $(0.042)$ & $(0.039)$ \\
\hline \multirow[t]{2}{*}{ Group shock * firm Q } & -0.002 & & & -0.002 & -0.002 & & & -0.002 \\
\hline & $(0.003)$ & & & $(0.002)$ & $(0.003)$ & & & $(0.003)$ \\
\hline \multirow[t]{2}{*}{ Group shock * relative Q } & & -0.003 & & & & -0.004 & & \\
\hline & & $(0.003)$ & & & & $(0.003)$ & & \\
\hline \multirow[t]{2}{*}{ Group shock * group Q } & & & -0.013 & -0.011 & & & -0.013 & -0.011 \\
\hline & & & $(0.022)$ & $(0.020)$ & & & $(0.022)$ & $(0.020)$ \\
\hline Sample size & 14253 & 14253 & 14253 & 14253 & 14253 & 14253 & 14253 & 14253 \\
\hline R-squared & 0.441 & 0.447 & 0.442 & 0.442 & 0.435 & 0.441 & 0.435 & 0.435 \\
\hline
\end{tabular}

Note: Robust standard errors clustered at the firm level appear below the coefficients. All models include firm size, year fixed effects, and firm fixed effects. 
Next, we turn our attention to further developing our own knowledge-based, recombinative capabilities view of business groups. Building on our earlier tables, which showed that groups systematically are more engaged in value-added activities and react to shocks with a large increase in the utilization of those valueadded activities, here we show that groups have maintained a profit edge over stand-alones during the entire 1989-2008 period. We also find that groups have far higher advertising intensity and R\&D intensity through the entire period of liberalization during 1989-2008. These findings differ from the predictions of all prior schools of thought about business groups as these prior schools of thought, all for the most part, predicted that there would be an obsolescence of business groups' profit and resource advantages with liberalization.

\begin{tabular}{|c|c|c|c|c|}
\hline Year & Group:Standalone ROA_BMM ratio & Group:Standalone ROA_NOINNRT ratio & $\begin{array}{r}\text { Multiplier In } \\
\text { Terms of } \\
\text { Advertising } \\
\text { Intensity } \\
\end{array}$ & $\begin{array}{l}\text { Group Multiplier In } \\
\text { Terms of R\&D Intensity }\end{array}$ \\
\hline 1989 & 1.08 & 1.08 & 1.44 & 253.83 \\
\hline 1990 & 1.10 & 1.10 & 1.98 & 128.15 \\
\hline 1991 & 1.08 & 1.12 & 1.79 & 2.14 \\
\hline 1992 & 1.14 & 1.21 & 1.66 & 3.10 \\
\hline 1993 & 1.20 & 1.19 & 1.50 & 2.60 \\
\hline 1994 & 1.12 & 1.12 & 1.57 & 2.28 \\
\hline 1995 & 1.17 & 1.18 & 1.61 & 2.28 \\
\hline 1996 & 1.23 & 1.23 & 1.79 & 2.06 \\
\hline 1997 & 1.24 & 1.21 & 1.70 & 2.69 \\
\hline 1998 & 1.25 & 1.20 & 1.85 & 2.70 \\
\hline 1999 & 1.23 & 1.21 & 1.92 & 5.17 \\
\hline 2000 & 1.12 & 1.10 & 1.65 & 2.66 \\
\hline 2001 & 1.30 & 1.27 & 1.47 & 2.06 \\
\hline 2002 & 1.14 & 1.12 & 1.47 & 2.39 \\
\hline 2003 & 1.25 & 1.23 & 1.37 & 2.44 \\
\hline 2004 & 1.22 & 1.22 & 1.55 & 2.53 \\
\hline 2005 & 1.18 & 1.19 & 1.40 & 2.08 \\
\hline 2006 & 1.16 & 1.16 & 1.47 & 0.98 \\
\hline 2007 & 1.18 & 1.18 & 1.43 & 1.74 \\
\hline 2008 & 1.15 & 1.18 & 1.42 & 1.70 \\
\hline
\end{tabular}

Note: The first column above uses PBDITA when calculating ROA whereas the second uses PBDIT net or NOI and NNRT.

Note: In the last column, the first two cell values are so large because stand-alones were doing only a trivial amount of R\&D in those two years. In that same last column, the multiplier suddenly dropped temporarily in 2006 because of one stand-alone making a particularly large R\&D investment that year. 


\section{Table 13. Indian Business Groups Growing Larger and More Diversified After Liberalization and After Market Development}

In this table, we show that Indian business groups actually became larger and more diversified with liberalization. This finding runs contrary to the prediction of nearly all prior schools of thought about business groups, as these prior schools of thought each, for the most part, predicted that groups would become more focused/less diversified with liberalization. At the same time, we also show in this table that Indian business groups have been increasingly diversifying over time into industries related to the ones in their existing portfolios.

\begin{tabular}{|c|c|c|c|c|}
\hline Year & Number of Groups & $\begin{array}{r}\text { Average Number of Group } \\
\text { Affiliates }\end{array}$ & $\begin{array}{r}\text { Average Number of Industries } \\
\text { Per Group }\end{array}$ & $\begin{array}{r}\text { Industry Relatedness Index based on } \\
\text { Maximum Input-Output Industry } \\
\text { Dependence }\end{array}$ \\
\hline 1989 & 347 & 2.4 & 1.9 & 9.879 \\
\hline 1990 & 374 & 2.7 & 2.1 & 11.271 \\
\hline 1991 & 443 & 2.9 & 2.2 & 10.252 \\
\hline 1992 & 480 & 3.1 & 2.3 & 10.314 \\
\hline 1993 & 520 & 3.3 & 2.4 & 11.351 \\
\hline 1994 & 561 & 3.5 & 2.5 & 11.684 \\
\hline 1995 & 568 & 3.9 & 2.8 & 12.489 \\
\hline 1996 & 568 & 4.1 & 2.8 & 13.085 \\
\hline 1997 & 556 & 4.2 & 2.9 & 12.813 \\
\hline 1998 & 555 & 4.4 & 3.0 & 13.027 \\
\hline 1999 & 568 & 4.6 & 3.0 & 13.003 \\
\hline 2000 & 564 & 4.7 & 3.1 & 12.559 \\
\hline 2001 & 564 & 4.6 & 3.0 & 12.399 \\
\hline 2002 & 562 & 4.8 & 3.2 & 12.522 \\
\hline 2003 & 558 & 5.6 & 3.5 & 12.707 \\
\hline 2004 & 557 & 6.0 & 3.7 & 13.246 \\
\hline 2005 & 554 & 6.0 & 3.7 & 12.930 \\
\hline 2006 & 550 & 5.9 & 3.6 & 13.312 \\
\hline 2007 & 543 & 5.9 & 3.6 & 13.285 \\
\hline 2008 & 521 & 5.8 & 3.5 & 13.321 \\
\hline
\end{tabular}

